\title{
Rhetoric and argument in social and environmental reporting: the Dirty Laundry case
}

Brennan, N.M.; Merkl-Davies, D.M.

\section{Accounting, Auditing and Accountability Journal}

DOI:

10.1108/AAAJ-04-2013-1333

Published: 01/11/2014

Peer reviewed version

Cyswllt i'r cyhoeddiad / Link to publication

Dyfyniad o'r fersiwn a gyhoeddwyd / Citation for published version (APA):

Brennan, N. M., \& Merkl-Davies, D. M. (2014). Rhetoric and argument in social and environmental reporting: the Dirty Laundry case. Accounting, Auditing and Accountability Journal, 27(4). https://doi.org/10.1108/AAAJ-04-2013-1333

\section{Hawliau Cyffredinol / General rights}

Copyright and moral rights for the publications made accessible in the public portal are retained by the authors and/or other copyright owners and it is a condition of accessing publications that users recognise and abide by the legal requirements associated with these rights.

- Users may download and print one copy of any publication from the public portal for the purpose of private study or research

- You may not further distribute the material or use it for any profit-making activity or commercial gain

- You may freely distribute the URL identifying the publication in the public portal ?

Take down policy

This article is (c) Emerald Group Publishing and permission has been granted for this version to appear here. Emerald does not grant permission for this article to be further copied/distributed or hosted elsewhere without the express permission from Emerald Group Publishing Limited.

Take down policy

If you believe that this document breaches copyright please contact us providing details, and we will remove access to the work immediately and investigate your claim. 


\title{
Rhetoric and Argument in Social and Environmental Reporting: The Dirty Laundry Case
}

\author{
Niamh M. Brennan \\ University College Dublin, Ireland \\ and \\ Doris M. Merkl-Davies \\ Bangor Business School, Bangor University, UK
}

An earlier draft of the paper was written while Doris Merkl-Davies was a visiting scholar at the University of Sydney Business School whose support we gratefully acknowledge. We also thank participants at the following conferences/seminars for helpful comments on earlier drafts of the paper: British Accounting \& Finance Association 2012; Irish Accounting \& Finance Association 2012; Accounting \& Finance Association of Australia and New Zealand 2012; University of Exeter; Newcastle Business School, Northumbria University; University of Victoria, Melbourne; University of Canterbury at Christchurch, University of Bristol, Edinburgh University. We thank Annika Beelitz for her preparation of Figure 1 in the paper. 


\title{
Rhetoric and Argument in Social and Environmental Reporting: The Dirty Laundry Case
}

\begin{abstract}
Purpose - This paper explores the interactive element in social and environmental reporting during a controversy between business organisations and a stakeholder over environmental performance.
\end{abstract}

Design/methodology/approach - We adopt Aristotle's triangular framework of the rhetorical situation to examine how the writer, the audience, and the purpose of communication interact in the choice of rhetorical strategies used to persuade others of the validity and legitimacy of a claim during a public controversy. Our analysis focuses on the strategies (i.e., moves and their rhetorical realisations in the form of on logos (appealing to logic), ethos (appealing to authority), and pathos (appealing to emotion), with a particular emphasis on metaphor, used to achieve social and political goals. We base our analysis on a case study involving a conflict between Greenpeace and six organisations in the sportswear/fashion industry over wastewater discharge of hazardous chemicals. The conflict played out in a series of 20 press releases issued by the parties over a two-month period.

Findings - All six firms interacting with Greenpeace in the form of press releases eventually conceded to Greenpeace's demand to eliminate hazardous chemicals from their supply chains. We attribute this to Greenpeace's ability to harness support from other key stakeholders and to use rhetoric effectively. Results show the extensive use of rhetoric by all parties.

Originality/value - We regard legitimacy construction as reliant on communication and as being achieved by organisations participating in a dialogue with stakeholders. For this purpose, we develop an analytical framework which situates environmental reporting in a specific rhetorical situation and links rhetoric, argument, and metaphor.

Keywords Rhetoric, Argument, Environmental reporting, Stakeholder, Greenpeace.

Paper type Research paper 
As humans, we don't absorb ... experiences as abstractions; we take them personally. And that's [what metaphors do]: taking the universal into the particular. (Anne Michaels) (Crown, 2009)

\section{Introduction}

This paper focuses on the interactive element in social and environmental reporting during a legitimacy threat in the form of a controversy between business organisations and a stakeholder over environmental performance. Prior studies on organisational legitimacy threats focus on the analysis of corporate narrative documents, including press releases, annual reports and CSR reports (e.g., Ogden and Clarke, 2005; Linsley and Kajüter, 2008; De Tienne and Lewis, 2005; Castelló and Lozano, 2011). Stakeholder communications relating to violations of social norms and rules or stakeholder values and beliefs are treated as part of the organisational context which is described in order to shed light on corporate reporting (e.g., Hooghiemstra, 2000). An exception is Massey (2001) who, in an experimental setting, finds that the crisis-response consistency of communication by organisations influences perceptions of organisational legitimacy. Thus, most prior research presumes that organisations are in control of legitimacy construction. By contrast, we adopt a relational view by regarding legitimacy as being constructed between organisations and their audiences in a 'process of reciprocal influence' (Ginzel et al., 2004, p. 225). This is in line with Suchman's (1995) discussion of moral legitimacy which arises from a positive normative evaluation of an organisation and its activities by its audiences. As judgements are formed through public discussion, legitimacy is reliant on communication and is achieved by organisations participating in social dialogue (Suchman, 1995, p. 585; Tregidga et al., 2007, p. 5).

We examine a conflict between Greenpeace and international sportswear/fashion firms over environmental performance. Complementary prior research has analysed the dialogic nature of verbal interactions between the parties involved in this controversy (Brennan et al., 2013). The focus of analysis in this paper is on the use of rhetoric and argument by both sides as a means of influencing audiences' opinions of the issue of contention, namely the use of hazardous chemicals in organisational supply chains. For this purpose we build on Aristotle's (2010) triangular framework of logos (appealing to logic), ethos (appealing to authority), and pathos (appealing to emotion) and insights from the 'New Rhetoric' movement. We show the outcome of the conflict, which entailed all firms conceding to Greenpeace's demand, to be dependent on Greenpeace's power and legitimacy and the urgency of its claim. 
Research questions were developed abductively during an iterative process of going backwards and forwards between theories and concepts and data. The overarching research question is: How do parties in a conflict over corporate environmental performance interact? We subdivide this overarching research question into three sub-questions: (1) How does the rhetorical situation/social context influence the interactions? (2) What moves do the parties make in the conflict? (3) How are those moves realised rhetorically?

The publication of Greenpeace's 'Dirty Laundry' report in July 2011 marked the start of what it referred to as its 'Detox' campaign. It alleged that 18 brands (16 firms) were using hazardous chemicals in their textile manufacturing processes. This was followed by a second report, 'Hung out to Dry', in August 2011. The purpose of the campaign was twofold, namely (1) to voice its concern regarding the industry's failure to safeguard environmental standards throughout its supply chains and (2) to draw public attention to this failure with the intention of pressurising the firms to take corrective action. This controversy played out in a series of 20 press releases issued by both sides (Greenpeace and six sportswear/fashion firms) over a twomonth period. Three of the six firms responding to Greenpeace's accusation of misconduct disputed Greenpeace's claims (NIKE, adidas, H\&M), while three (PUMA, LACOSTE and GStar RAW) conceded to Greenpeace's demand. Greenpeace used negative publicity to pressurise the initially unyielding firms to comply with its demand. Our findings show the extensive use of rhetoric by all parties involved in the conflict. Greenpeace used metaphors that resonate with the firms' key stakeholders, i.e., consumers and the media (metaphors of housekeeping, size, racing, sport and fashion), in order to coerce the firms to agree to eliminate hazardous chemicals from their supply chains by 2020. The sportswear/fashion firms responded by using metaphors which redefine the constructs of competition and speed inherent in Greenpeace's claims (metaphors of journey, complexity and co-operation).

Our paper builds on three streams of literature: (1) research that views social and environmental reporting as relational - as such we respond to Bebbington et al.'s (2007) call to apply dialogic thinking to social and environmental reporting; (2) research on crisis management and organisational responses to legitimacy threats; and (3) research analysing corporate reporting and communication using text analysis approaches based on the concepts of rhetoric and argument. For this purpose, we extend the work of Brennan and Gray (2000) and Brennan et al. (2010) on interaction during takeovers to a social and environmental context by building on 
the work of Coupland (2005) and Higgins and Walker (2012) on rhetoric and argument in social and environmental reporting.

The paper makes four contributions to the literature. First, we introduce a dynamic and interactive element to stakeholder theory which is based on the view of conflict resolution between organisations and a stakeholder as dependent on the stakeholder's power, legitimacy, and the urgency of its claim. Power constitutes the ability to achieve intended outcomes and results from access to material and symbolic resources, including the ability to mobilise support from other key stakeholders. Rhetorical skill is crucial in gaining support by persuading audiences that firms' environmental practices and policies violate social norms and rules relating to pollution. Second, our analysis focuses on interactions in the form of moves (i.e., speech acts or discursive strategies whose objective is to achieve a specific social purpose, such as excusing, threatening, or apologising) between parties involved in the conflict. Third, we develop an analytical framework which situates environmental reporting in a specific rhetorical situation and links rhetoric, argument, and metaphor. Fourth, we highlight the use of metaphor as a powerful means of persuasion in public controversies.

The remainder of the paper comprises five sections. First, we review the literature on social and environmental reporting, including theoretical perspectives and rhetorical approaches. In Section 3 we outline the relationship between social and environmental reporting, rhetoric and metaphor. Then, we provide an overview of the data, consisting of 20 press releases by Greenpeace and by six sportswear/fashion firms, and set out the analytical framework and the categories of analysis. Next, we apply the analytical framework developed in Section 4 to the analysis of rhetoric and argument in the 'Dirty Laundry' case and discuss findings. The paper concludes in Section 6 with a summary and recommendations for future research.

\section{Prior literature}

We first review the relevant literature on social and environmental reporting, then discuss predominant theoretical perspectives adopted in research on organisational crises in the form of legitimacy threats or public controversies, and finally consider research on the use of rhetoric and argument in corporate narrative reporting. 


\subsection{Social and environmental reporting}

Social and environmental reporting has variously been described as "the process of communicating the social and environmental effects of organisations' economic actions to particular interest groups within society and to society at large" (Gray et al, 1987, p. ix) and as an "extension of disclosure into non-traditional areas such as providing information about employees, products, community service and the prevention or reduction of pollution" (Mathews and Perera, 1985, p. 364). We build on the literature focusing on the role of social and environmental reporting following organisational legitimacy threats or crises caused by organisational 'wrongdoing' (Ashforth and Gibbs, 1990) or misconduct (Ketola, 2006, 2008). Corporate social and environmental reporting is used as a means of demonstrating that the organisation has realigned its practices, policies, and performance in line with expectations of organisational audiences (retrospective focus). The focus of analysis is on the strategies used in corporate narrative documents to restore legitimacy after a corporate scandal, environmental disaster, or product failure. For example, Elsbach (1994) and Linsley and Kajüter (2008) analyse the use of verbal remedial strategies, such as excuses, apologies, and justifications, to separate the negative event from the organisation as a whole. In this context, Beelitz and MerklDavies (2012) differentiate between real changes in processes and procedures (substantive management) and merely superficial changes in the form of executive replacement or the creation of monitors and watchdogs (symbolic management). The latter makes the organisation appear to respond to social pressures exerted by the general public, the media, or a particular stakeholder.

However, social and environmental reporting also plays a crucial role during organisational crises or public controversies between an organisation and a particular stakeholder as a means of resolving the conflict by shaping audiences' attitudes towards the issue of contention (prospective focus). A study of the use of rhetoric and argument by organisations and a key stakeholder during a public controversy can add insights to our understanding of the ways in which social and environmental reporting is used to influence audiences' opinions of a problem, in our case water pollution in supply chains. Indeed, research suggests that the use of rhetoric and argument is particularly pronounced during public controversies, conflicts over values, or shortfalls in corporate social and environmental performance (Suddaby and Greenwood, 2005; Coupland, 2005), as organisations depend on public approval and thus need to 'engineer' public support (Bernays, 1947). 
Press releases are an established means for both commercial and non-commercial organisations to communicate with their audiences. They are used by firms to keep their relevant publics, e.g., shareholders, customers, or employees, informed on a variety of issues, including social and environmental practices and policies. During a conflict or public controversy corporate press releases are used to state the firm's position on the contested issue. By contrast, noncommercial organisations, such as Non-Government Organisations (NGOs), trade unions, or public bodies, use press releases to initiate a public dialogue about a particular issue. Alternatively, press releases by non-commercial organisations may be prompted by a disagreement with the action, non-action, or controversial action of a specific industry or company.

Target audiences for corporate social and environmental reporting are complex. Social and environmental reports are sent to shareholders who tend to be the primary audience for such information. However, managers are aware of other parties who also access these public documents, including, inter alia, various stakeholders, NGOs, social pressure groups, the media, and government. Social and environmental reporting constitutes a means of responding to social pressures exerted either by the public at large or by specific stakeholders in particular. It may be used to demonstrate that organisational practices, policies, and performance are in line with social norms and rules and/or with the values and beliefs of key stakeholders.

\subsection{Theoretical perspectives}

Organisational crises and public controversies between a business organisation and a stakeholder have been studied through a variety of theoretical lenses, including the theory of image restoration (Benoit, 1997; Benoit and Czerwinski, 1997), legitimacy theory (Elsbach, 2001; Ogden and Clarke, 2005; Beelitz and Merkl-Davies, 2012), and stakeholder theory (Hooghiemstra, 2000). Wood (1991) differentiates between the concepts of legitimacy and public responsibility. Legitimacy refers to the perception of organisational behaviour as being in line with social norms and rules. By contrast, public responsibility indicates that organisational practices and policies are perceived as conforming to the specific values and beliefs of a particular stakeholder. Both legitimacy and public responsibility refer to audience perceptions of the desirability and appropriateness of organisational actions within a socially constructed system of norms, values, and beliefs (Suchman, 1995, p. 574). This means that legitimacy and public responsibility are granted, withheld, or questioned by audiences. Stakeholders, particularly social movements and NGOs, perform the important functions of 
monitoring and challenging organisational behaviour (Hooghiemstra, 2000; Cooper, 2009; Joutsenvirta, 2011). Challenges of organisational behaviour may result in legitimacy threats, if the stakeholder's socially constructed value system is congruent with that of society.

Stakeholders are persons, groups, or organisations that have a direct or indirect stake in an organisation because they can affect or be affected by the organisation's actions, objectives, and policies (Freeman, 1984). As firms depend on stakeholders for resources, such as finance, labour, and patronage, a good relationship between the two parties is crucial for organisational survival (Jawahar and McLaughlin, 2001). In their review of stakeholder theory, Mitchell et al. (1997) identify three key stakeholder attributes, namely power, legitimacy and urgency. These three aspects impact on stakeholder salience (the degree to which managers give priority to competing stakeholder claims). The three stakeholder attributes are discussed in more detail in Section 4.3 of the paper where we apply the framework to the analysis of the 'Dirty Laundry' case. Mitchell et al. (1997) further differentiate between stakeholders who have a legal or moral claim on organisations and stakeholders who have the ability to influence organisational behaviour, processes, or outcomes. The former consist of employees, suppliers, and debt and capital providers. The latter are also referred to as 'stakeseekers' (Fassin, 2009) in the sense that they seek to have an input into organisational decision-making processes and include NGOs, pressure groups, and social movements. Similarly, Holzer (2008, p. 52), citing Heath (1997), distinguishes between constituents who have vested interests in the organisation (e.g., employees, trade unions, and suppliers) and those that do not have organisationally defined links, but claim new stakes. Environmental NGOs, such as Greenpeace and the World Wildlife Fund, fall into the latter group, as they are not formally linked to business organisations, yet seek to influence their environmental activities, performance, and reporting. Prior research shows that NGOs are able to challenge corporations in the form of direct action campaigns, such as the McLibel trial (Vidal, 1997), Greenpeace's campaign against Shell concerning the Brent Spar oil platform (Tsoukas, 1999, Hooghiemstra, 2000), and the 'No Sweat' campaign against major clothing manufacturers (Ross, 1997). Conflicts between a business organisation and an NGO are more likely to be resolved in favour of the NGO, if the NGO's values and beliefs are shared by the general public, the media, and other key stakeholders.

\subsection{Rhetoric in corporate narrative reporting research}

Organisations use rhetoric retrospectively to respond to existing rhetorical situations or proactively to shape or frame future rhetorical situations (Cheney et al., 2004, p. 87). Rhetoric 
serves to resolve both overt and covert conflicts and to avoid conflict in the first place. It constitutes a powerful means of manufacturing consent by using dominant discourses. Rhetorical approaches emphasise either the strategic or political nature of corporate narrative reporting and communication. The underlying assumption is that the purpose of corporate narrative reporting and communication is to achieve specific communicative or political goals, such as convincing financial stakeholders of the financial soundness or creditworthiness of the company, persuading organisational audiences of the company's environmental credentials (Higgins and Walker, 2012), persuading stakeholders to accept planned structural reorganisation, such as privatisation (Craig and Amernic, 2004a, 2008), reinforcing capitalist ideology, or securing hegemony.

However, there is little research on the use of rhetoric by a powerful stakeholder, such as Greenpeace, Amnesty International, or the World Wildlife Fund, as a means of persuading organisations to review their values or improve their social and environmental performance. In the case of an overt conflict between an organisation and a stakeholder, the goal is to convince both the other party and relevant publics, including the media, of the validity of a particular point of view or of the necessity and legitimacy of a particular course of action.

\section{Rhetoric and argument}

We consider rhetoric and argument to be communicative resources which are used to achieve intended outcomes. Our view of rhetoric is informed by insights of theorists of the 'New Rhetoric' movement who regard rhetoric as an essential constituent part of social interaction and communication, rather than mere ornamentation of speech. This is linked to the ideas of the so-called 'ordinary language philosophers' of the 1950s and 1960s, such as Austin (1962) and Searle (1969) who view language as action, i.e., 'doing things with words' (Austin, 1962). Everett and Neu (2000, p. 7) observe that "language ... 'activates' reality and makes reality meaningful." Wetherall and Potter (1988) emphasise the action orientation of language use and its use to achieve particular consequences. Billig et al. (1988) argue that the use of contrary themes is valuable in argumentation and deliberation in social dilemmas. They discuss the use of reasons, arguments justifications and criticisms, the use of pros and cons, and the use of opposing images, words, evaluations and maxims in arguing about dilemmas. Arguments constitute the verbal means by which speakers/writers aim to exert influence on their audience in a verbal exchange (Amossy, 2001). Arguments consist of three elements: (1) the claims or statements made, (2) the assumptions or beliefs underlying these statements, and (3) the 
evidence provided for the claims. Evidence for a claim is provided by means of rhetoric which "is the science and art of persuasive language use" (Reisigl, 2008, p. 96). Rhetoric constitutes a means of influencing others' opinions of an issue (e.g., pollution) or of persuading others to change their attitudes, beliefs, values or actions (Cheney et al., 2004, p. 80). Due to their function as both heuristic and persuasive devices, metaphors play a central role in rhetoric and argument.

\subsection{Rhetorical strategies}

Our rhetorical framework is based on classical Aristotelian rhetoric which differentiates between three types of rhetorical strategies: logos (appeal to logic), ethos (appeal to values or to the authority of the speaker / a respected person or organisation), and pathos (appeal to emotion). Logos aims to convince audiences by using facts and figures to back up a claim. It involves using discourse from the domains of science, technology, bureaucracy, law and business to persuade audiences of the validity and legitimacy of the claim. In the context of environmental reporting, logos is of particular importance, as the discourse of ecological modernisation, which predominates in debates on environmental issues, is based on the "accumulation of scientific evidence of environmental impacts" (Harvey, 1998, p. 343; quoted in Everett and Neu, 2000, p. 11). Constructing pollution based on the principles of scientific management thus constitutes a widely accepted way of constructing an argument. What is more, it makes the speaker/writer seem knowledgeable, thus enhancing their authority (ethos). Ethos is used to persuade audiences by either appealing to the authority of the speaker/writer, the authority of another social actor (e.g., an expert, an independent authority or a person of high social or moral standing in the community), or the authority of the law. This is particularly important in debates on environmental issues, as environmental standards and regulations are regarded as a means of safeguarding the environment from harm caused by economic activity (Everett and Neu, 2000). Finally, pathos is aimed at influencing audience attitudes by evoking an emotional response. It involves the use of figurative language, particularly metaphor (Charteris-Black, 2004, 2005).

\subsection{Metaphors}

Metaphors involve an implied comparison between two entities, achieved through a figurative use of words (e.g., top management, fringe benefits, and front-line staff). They entail "understanding and experiencing one kind of thing in terms of another" (Lakoff and Johnson, 1980, p. 5). For example, we conventionally conceptualise money as liquid (e.g., cash flow, 
$\underline{\text { liquidation }}$ of a firm, to run out of money) or organisations as machines (e.g., human resources, communication has broken down). Metaphors are powerful conceptual devices (Morgan, 1980, 1983, 1993), as they indicate particular ways of thinking and seeing in the sense that "the[ir] use...involves cognitive processes which structure thought and behaviour" (Amernic and Craig, 2009, p. 878). As highlighted by the linguistic 'turn' in the social sciences, social phenomena are perceived only in terms of the images used to represent them (Gabriel, 2004, p. 63). Thus, metaphors play a key role in knowledge construction and constitute "a way of knowing" (Walters, 2004, p. 160). Metaphors govern how events and issues are interpreted and communicated. Making claims or statements invariably involves the use of metaphors. Metaphors reinforce specific perceptions and ways of thinking about an issue while ignoring others. For this reason, they not only function as a means of knowledge construction, but also as a means of perception engineering (Walters, 2004). Metaphors thus play a key role in influencing others' thinking and behaviour. This means that they are intrinsically rhetorical. Thibodeau and Boroditsky (2011) test the persuasive power of metaphor in an experiment. They show that people's thinking and behaviour are influenced by the metaphors used to present a problem. When crime is presented as a 'beast', people are more likely to approve of strong law enforcement. By contrast, when it is described as a 'virus' infecting society, people are more receptive to rehabilitation and understanding of the causes of crime. The same holds for environmental metaphors. For example, using the metaphors of 'mother nature' as opposed to nature as a 'resource' denotes a specific view of the relationship between business organisations and the natural environment which, in turn, makes specific ways of acting possible, while excluding others.

Metaphors are also indicative of social actors' underlying values and beliefs. They provide an insight into the assumptions underlying a claim or statement made on a particular issue. For this reason, metaphors play an instrumental role in constructing and reproducing ideologies and justifying social action and behaviour. In fact, the persuasive power of metaphors lies in their ability to "tap ... into an accepted communal system of values" (Charteris-Black, 2004, p. 12). They are thus a common feature in the speeches of political and corporate leaders (see, for example, Amernic et al., 2007; Charteris-Black, 2005; Cox, 2012) and constitute a prevalent feature in corporate reporting and communication (Beelitz and Merkl-Davies, 2012; Craig and Amernic, 2004b; Crowther et al., 2006). Goatly (2007) argues that there are patterns of metaphors which are associated with the dominant capitalist ideology which underpins Western societies. Ideologies are social beliefs shared by a group of people which are used to 
further their interests. The basic beliefs of an ideology organise specific attitudes (socially shared opinions) about an issue, such as immigration or pollution. Some groups of people are more powerful than others which results in the dominance of specific ideologies. Language, meaning and power are interlinked. For this reason, the use of metaphors associated with dominant ideologies affect the way we think and act, thus reinforcing social inequality, injustice, and environmental exploitation. The ideology of capitalism is characterised by "the impulse to acquisition, pursuit of gain, of money, of the greatest possible amount of money" (Weber, 1958, p. 17). Metaphors associated with the capitalist system include metaphors of power (e.g., activity is conceptualised as fighting as in 'takeover') and metaphors for humans and the living world (e.g., human beings are conceptualised as machines as in 'human resources'). In the same vein, the dominant discourse of sustainable development conceptualises nature as a 'resource' requiring expert human management (McGregor, 2004, p. 596). Metaphors tend to occur in the form of differentiation, i.e., significant pairings, contrasts, or dualisms, such as up-down, mind-body, public-private, etc. which are often seen "in contradiction to each other, frequently with one term assuming dominance" (Llewellyn, 2003, p. 670).

\subsection{Rhetorical situation}

Rhetoric is embedded in the 'rhetorical situation', i.e., the social context in which the verbal interaction takes place. The rhetorical situation consists of three interrelated elements: (1) the speaker/writer, (2) the audience(s), and (3) the purpose of communication. Due to the public nature of press releases, they are directed at multiple audiences. DeRosa and Ferruci (2011) differentiate between the primary/target/stated audience (the other party/parties involved in the conflict) and secondary/wider/implied audiences (the wider public, such as consumers, the media, and shareholders). Press releases therefore have multiple purposes directed at the primary/target/stated audience and at secondary/wider/implied audiences. Business organisations thus address multiple audiences, including one another (Cheney et al., 2004, p. 86) through formal public messages, such as CEO speeches, mission statements, and public relations communication (Cheney et al., 2004, p. 81).

\section{Data and methodology}

We analyse the use of rhetoric and argument in a public controversy between Greenpeace and international sportswear/fashion firms over the use of hazardous chemicals in their supply chains. The conflict resulted from the firms' environmental practices and policies violating 
Greenpeace's norms and rules with respect to pollution. It played out in the form of 20 press releases issued by Greenpeace and six sportswear/fashion firms (adidas, G-Star RAW, H\&M, LACOSTE, NIKE and PUMA) over a two-month period.

\subsection{The 'Dirty Laundry' case}

In July 2011 Greenpeace issued a press release highlighting the findings of its 'Dirty Laundry' report on water pollution in China and Southeast Asia. This marked the start of Greenpeace's 'Detox' campaign focusing on the elimination of hazardous chemicals in the supply chains of international sportswear/fashion firms. In August 2011 Greenpeace published a second report, 'Hung out to Dry'. Following Greenpeace's first press release, 19 subsequent press releases were exchanged over a two month period, six from Greenpeace and 13 from the six firms referred to above. As the events and the exchanges of press releases took place over a fairly short period of time, the resulting dataset is suitable for a fine-grained analysis of rhetoric and argument. The advantage of rhetorical analysis (as opposed to content analysis) is its sensitivity to linguistic nuances and contextual features.

The summary timeline of key events shown in Figure 1 indicates that Greenpeace used both 'peaceful protest' and 'creative communication' in the 'Detox' campaign, as outlined in its mission statement. The purpose of both strategies is to achieve its dual aims to 'expose global environmental problems' and 'promote solutions that are essential to a green and peaceful future' (Greenpeace USA, 2013, p. 1). In the 'Dirty Laundry' case this entailed drawing public attention to the harmful environmental practices of the sportswear/fashion industry and pressurising firms to change them in order to protect the environment from pollution. For this purpose, Greenpeace drew on its social capital (its social connections allowing it to advance its interests) in order to mobilise activists to participate in key events, including (i) a protest outside the world's largest adidas store and a NIKE store in Beijing, (ii) an online petition signed by thousands of people, (iii) a record-breaking striptease in front of adidas and NIKE stores worldwide, (iv) a public reprimand to adidas at a European cup football match watched on TV worldwide, (v) activists stringing out t-shirt shaped banners over the Marikina river in Manila, and (vi) a week-long campaign of attaching protest stickers to H\&M shop windows. Greenpeace also extensively used social media networks to exert pressure on sportswear/fashion firms. The 'Detox' campaign was characterised by two elements which Bernays (1947) highlighted in his work on public relations, namely the vivid dramatisation of events for those who do not witness them and the constant creation of news to capture public 
attention. The negative publicity created by Greenpeace' social activism put pressure on the firms to concede to its demand.

Six months after the data was collected for this paper Greenpeace re-commenced its campaign in March 2012 by issuing its third report, 'Dirty Laundry - Reloaded'. It does not appear to have generated press release responses from sportswear/fashion firms, thus making it less suitable for the analysis of rhetoric and argument applied in this paper. In November 2012 Greenpeace issued another report, 'Toxic Threads - The Big Fashion Stitch-Up', which outlined the results of Greenpeace's investigation of the presence of hazardous chemicals in the clothes of 20 fashion brands. Zara conceded immediately in similar manner to PUMA outlined in our paper. These subsequent reports and press releases point to opportunities for further analysis of this case.

Figure 1: Timeline of key events

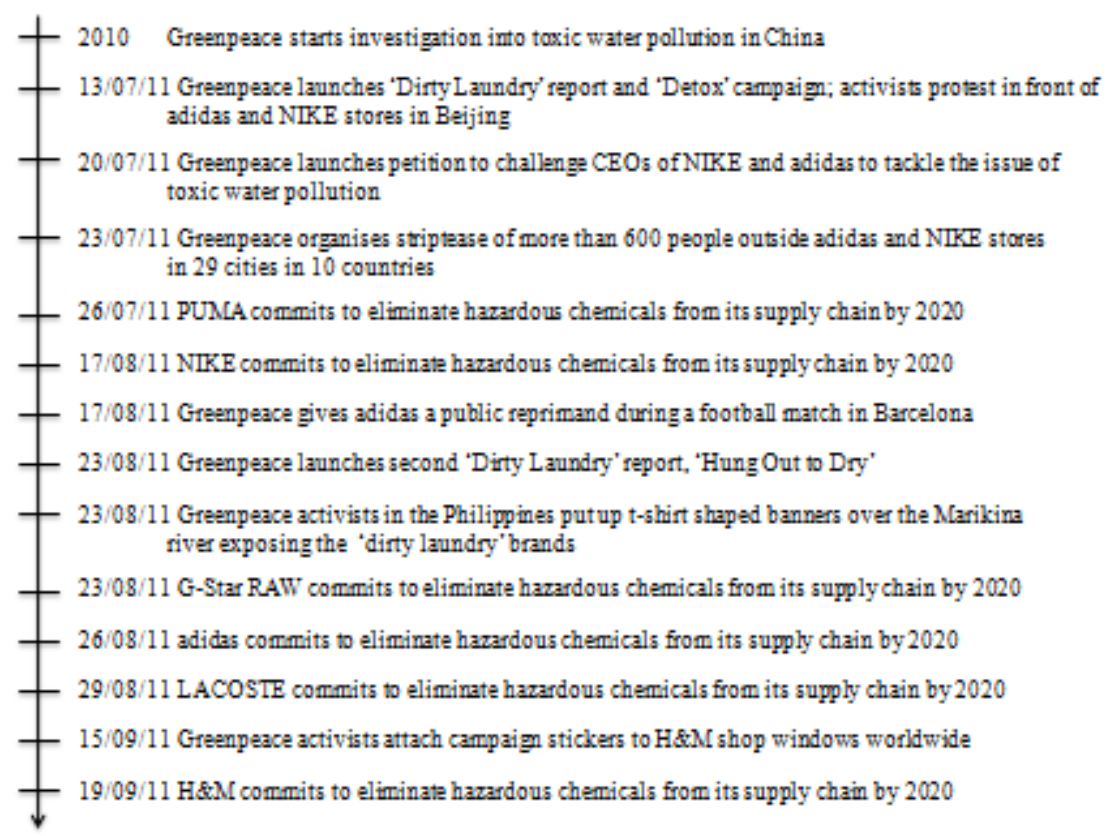

\subsection{The data}

Table 1 presents the 20 press releases in terms of chronology, issuing organisation, title and length. Length is measured as total sentences/phrases and as total number of words including notes to editors (a particular feature of the Greenpeace press releases), footnotes, but excluding 
contact details. While website addresses were included in the calculation of length, they did not form part of the rhetorical analysis. 


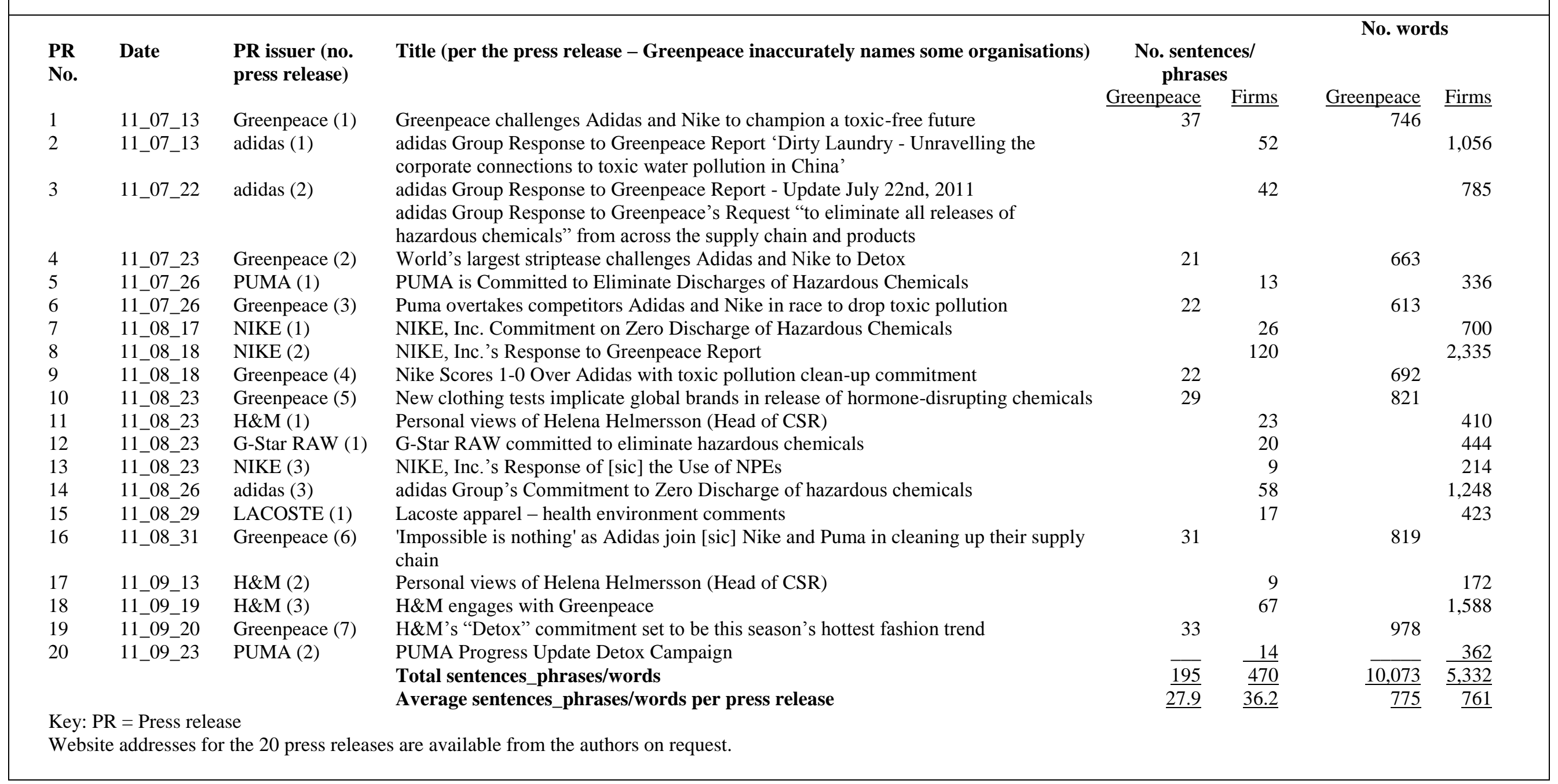




\subsection{Analytical framework}

Our view of language as an inherently social activity results in an analytical framework consisting of two levels of analysis, namely (1) an analysis of the rhetorical situation (social context) in which the press releases are embedded and (2) a rhetorical analysis of the 20 press releases exchanged by Greenpeace and the fashion/sportswear firms (text). The analysis of the rhetorical situation utilises Mitchell et al.'s (1997) framework and focuses on the relationship between Greenpeace and the fashion/sportswear firms and their relationships with other organisational stakeholders and the media. The rhetorical analysis is based on the view of rhetoric and argument as social action and focuses on the strategies (i.e., moves and their rhetorical realisations in the form of logos, ethos, and pathos, including metaphors) used to achieve social and political goals.

The analytical framework and categories of analysis, resulting in Figures 2, 3, and 4, were developed abductively in an iterative process of going backwards and forwards between the theories and concepts introduced in the prior section of the paper and the data. The data analysis and interpretation was preceded by the authors familiarising themselves with Mitchell et al.'s (1997) framework of stakeholder identification introduced in Section 2.2 and the theories and concepts relating to rhetoric and argument discussed in Section 3. This was followed by a number of close readings of the press releases issued by Greenpeace and the sportswear/fashion firms in order to provide a high level familiarity and understanding of the data. Following the close readings, initial categories of analysis were selected based on their ability to capture rhetoric and argument in the press releases. These were refined a number of times until we were satisfied that the analytical framework and categories of analysis were able to capture the dynamics of interaction between the parties involved in the conflict. We have made our analysis as transparent as possible, for example, by providing illustrative examples throughout the presentation of findings in Section 5, particularly in Tables 3, 4, 6 and 7.

\section{Categories of analysis}

We focus on the dynamics of verbal interaction between Greenpeace and the six sportswear/fashion firms involved in the 'Dirty Laundry' case. First, we conceptualise verbal interaction as a series of conversational units or moves which have a specific communicative purpose, such as accusing, demanding, requesting, threatening (Greenpeace) and denying, excusing, and conceding (sportswear/fashion firms). Ketola (2006, 2008) classifies organisational response to charges of misconduct based on whether the organisation (1) admits 
the misconduct and/or (2) admits responsibility for the misconduct. Combining the two possible responses, namely (1) admitting (or not admitting) the misconduct and/or (2) admitting (or not admitting) responsibility for the misconduct, results in four moves by the sportswear/fashion firms: denials, excuses, justifications, and concessions (see Figure 2). Denials involve the failure to admit to the misconduct and the refusal to take any responsibility for it. Excuses entail admitting to the misconduct, but refusing to take any responsibility for it. Justifications involve admitting responsibility for actions, but denying their harmful nature. Finally, concessions involve admitting both responsibility for actions and the harmful effects of environmental practices.

Second, we analyse on how the moves used during a verbal interaction between parties are realised in the form of rhetoric and argument. For this purpose, we focus on logos (appealing to logic), ethos (appealing to authority), and pathos (appealing to emotion), with a particular emphasis on metaphor. Third, we analyse the rhetorical use of metaphors. Metaphors work by conveying abstract concepts (such as money or time) in concrete terms (e.g., as physical objects, spatial orientations or fixed structures relating to everyday human experience). As people find it difficult to relate to abstractions, metaphors capture the audience's imagination. The more vivid the image conveyed by the metaphor, the stronger the emotional response and thus the greater its persuasive power.

Figure 2 operationalises the use of rhetoric and argument in the 'Dirty Laundry' case. Each argument is conceptualised as a move which is shown to consist of a specific claim, an underlying assumption, and evidence provided in the form of rhetoric, including the use of metaphors. It shows that Greenpeace used rhetoric prospectively to frame the issue of pollution by sportswear/fashion firms and the need to eliminate hazardous chemicals from their supply chains by using logos, ethos, and pathos (metaphors of housekeeping, size, racing, sport and fashion). By contrast, the sportswear/fashion firms used rhetoric reactively to either dispute Greenpeace's charge of misconduct by means of logos and ethos or to reframe the demand to eliminate hazardous chemicals from their supply chains by means of pathos (metaphors of journey, complexity, and co-operation) as a means of conceding to Greenpeace's demand on their terms. 
Figure 2: The use of rhetoric and argument in the 'Dirty Laundry' case

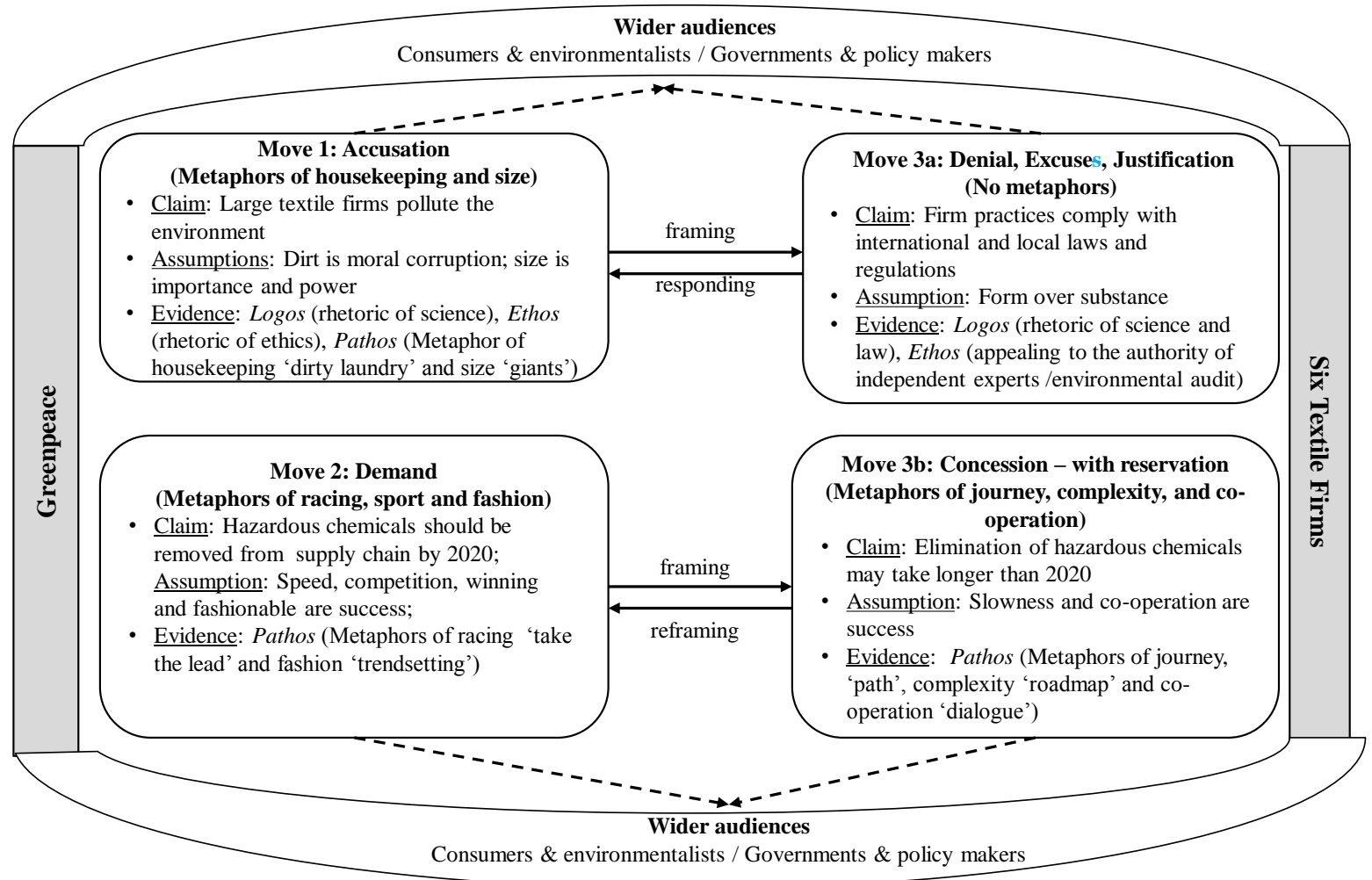

Key: $-\rightarrow$ Representing link between rhetoric (text) and rhetorical situation (context)

\section{Elements of the rhetorical situation}

Figure 3 applies the three elements of the rhetorical situation, i.e., (i) speakers/writers, (ii) (direct and indirect) audiences, and (iii) the purposes of communication to the 'Dirty Laundry' case. It shows that the press releases are not only directed at the other party involved in the conflict, but also at wider audiences, including environmental activists/Greenpeace supporters, consumers of fashion and sports goods, governments and policy makers, the general public, and the media. 
Figure 2: The rhetorical situation in the 'Dirty Laundry' case

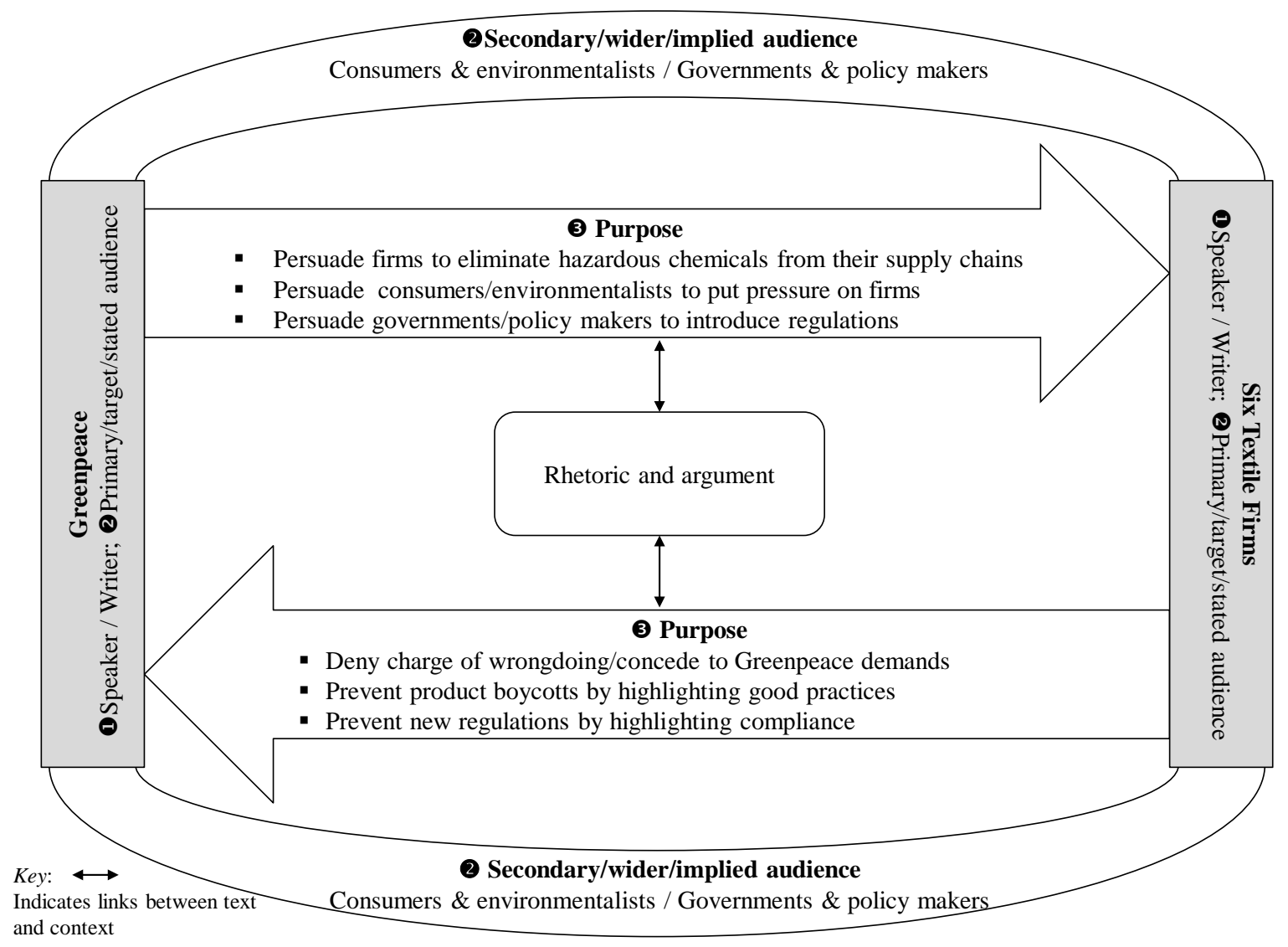

In order to identify the audiences for the press releases, we analysed the press releases for direct references to stakeholders. Table 2 indicates that Greenpeace was primarily concerned with its own supporters/activists, consumers, policy makers, and possibly with suppliers - to which it refers frequently. By contrast, the sportswear/fashion firms addressed their press releases mainly to Greenpeace and, to some extent, to their suppliers. 
Table 2: Audiences for the press releases - references to other parties

Primary/target/stated audience

Six sportswear/fashion firms

Greenpeace

Secondary/wider/implied audiences

Supporters /Activists

Consumers/Customers

Suppliers

Government/Policy

makers/Regulators

Non-governmental organisations

Workers/employees

Stakeholders/Communities/Civil

society

\section{Greenpeace Sportswear/fashion firms \\ No. references No. references}

$\underline{172}$

$\underline{64}$

$\begin{array}{rr}10 & 0 \\ 6 & 8 \\ 16 & 76 \\ 7 & 6 \\ - & \\ 0 & 8 \\ 1 & 1 \\ & 9 \\ 40 & \underline{108}\end{array}$

The presence of multiple audiences and purposes for social and environmental reporting in the 'Dirty Laundry' case necessitates a framework of analysis encompassing all relevant stakeholders. For this purpose, we use Mitchell et al.'s (1997) classification of stakeholder attributes introduced in Section 2.2, namely (1) power, (2) legitimacy, and (3) urgency. Power constitutes the ability to achieve intended outcomes and derives from the ability to access resources. Resources include both financial resources (e.g., donations) and symbolic resources, such as the relationship of the organisation with its relevant publics or stakeholders (e.g., donors and supporters, the general public, and the media) and staff knowledge and experience (e.g., public relations and communication skills). Legitimacy involves the perception of the desirability and appropriateness of the stakeholder's mission and actions by the general public and the media and can thus be considered a resource which is used to attract and maintain public support (Suchman, 1995, p. 575). In a conflict between firms and a stakeholder, this includes the stakeholder's ability to form alliances with customers, thus influencing the consumption of the organisation's goods and services. Urgency relates to the timesensitiveness or the importance of the stakeholder's claim. By combining their three relationship attributes, Mitchell et al. (1997) identify seven types of stakeholders, with examples for each type: (1) dormant (only power; e.g., employees who have been dismissed or have been made redundant), (2) discretionary (only legitimacy; e.g., beneficiaries of corporate philanthropy), (3) demanding (only urgency; e.g., lone picketer outside company premises), (4) dominant (power and legitimacy; e.g., shareholders, creditors, employees, customers, 
media, government/policy makers), (5) dependent (legitimacy and urgency; e.g., local residents affected by activities of the firm), (6) dangerous (power and urgency; e.g., wildcat strikers, employee saboteurs, terrorists) and (7) definitive (power, legitimacy and urgency; e.g., shareholder activists, whistleblowers). Alpaslan et al. (2009) argue that a crisis may trigger an increase in stakeholder salience by transforming dormant into dangerous stakeholders, discretionary into dependent stakeholders, and dominant into definitive stakeholders. This, in turn, changes the degree to which managers give priority to competing stakeholder claims.

We apply Mitchell et al.'s (1997) typology of stakeholder attributes to the 'Dirty Laundry' case in Figure 4. Stakeholders combining power, legitimacy and urgency constitute definitive stakeholders in the sense that organisations tend to prioritise such stakeholders' demand. Organisations also have strong incentives to resolve conflicts with this type of stakeholder quickly and satisfactorily for both parties. This is particularly the case for stakeholders who have the support of the wider public and the media, as the potential negative publicity associated with the conflict may damage the firm's image, reputation, or legitimacy. Large NGOs, such as Greenpeace or the World Wildlife Fund, are thus able to put considerable pressure on business organisations, particularly if these operate in industries characterised by strong public visibility, both in terms of media attention and the presence of a consumer audience (Carter, 2006). 


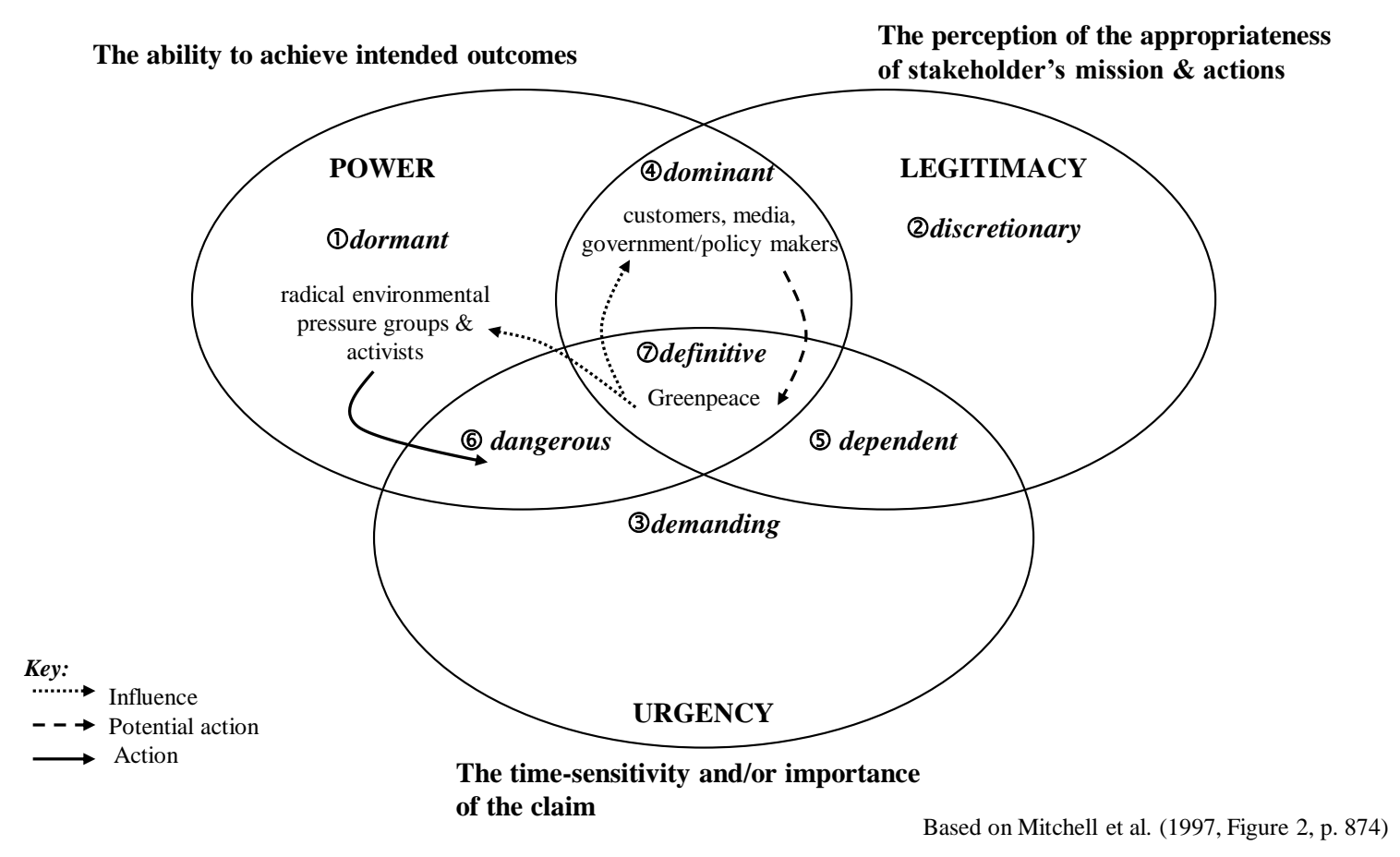

To summarise, our analytical framework comprises two levels, namely (1) a rhetorical analysis of press releases (text) and (2) an analysis of the rhetorical situation (social context). The rhetorical analysis focuses on the dynamics of interaction between the parties involved in the conflict in the form of moves (i.e., accusations, demand, denials, excuses, justifications and concessions) and their rhetorical realisation (in the form of logos, ethos, pathos), with a particular emphasis on metaphor as a means of appealing to emotion. The analysis of the rhetorical situation focuses on the relationships between the parties involved in the conflict, including their relationships with other stakeholders.

\section{Discussion of findings}

Figures 2, 3, and 4 visualise the application of the analytical framework developed in Section 4.3 to analyse the interaction between Greenpeace and sportswear/fashion firms in the 'Dirty Laundry' case. In this section, we first discuss the findings arising from Figure 2 relating to the dynamics of interaction between the parties. Illustrative examples to support our findings are provided in Table 3. We then discuss the findings arising from Figure 3 and Figure 4 relating to the rhetorical situation characterising the 'Dirty Laundry' case, including the relationship 
between stakeholders.

\subsection{Use of rhetoric and argument}

Both Greenpeace and the sportswear/fashion firms used rhetoric and argument in their press releases to address multiple audiences in order to achieve specific purposes (see Figure 3). This section considers the dynamics of verbal interaction between the parties involved in the dispute in the form of moves and the rhetorical strategies used to realise the moves, including metaphor. Metaphors are used as a means of evoking an emotional response, thus underlining the urgency of Greenpeace's claim both in terms its importance and speediness of response required. Table 3 provides illustrative examples in the form of quotes from the press releases.

\section{Dynamics of interaction: Moves}

The interaction between Greenpeace and the six sportswear/fashion firms took the form of four moves (see Table 3). Greenpeace initiated the interaction by accusing the sportswear/fashion firms of using hazardous chemicals in their supply chains (Move 1) and demanding their elimination by 2020 (Move 2). This involved the prospective use of rhetoric as a means of framing the projected rhetorical situation, thus putting Greenpeace firmly in the driving seat. The six sportswear/fashion firms used rhetoric retrospectively to respond to an existing rhetorical situation, namely Greenpeace's charge of misconduct and demand for action. Responses fall into two categories, namely responses to the charge of misconduct and responses to the demand for remedial action. adidas, NIKE, H\&M disputed Greenpeace's claim and defended their environmental practices (Move 3a - denials, excuses, justifications). By contrast, adidas excused its harmful environmental practices by shifting the responsibility onto its Chinese supplier by stating "Our business relationship with Youngor Group is restricted to the cutting and sewing of garments" Example 3.4 in Table 3). H\&M questioned the validity of Greenpeace's claims ("Our own result and audits done by an independent laboratory shows [sic] that the chemical has not been used" Example 3.13) and justified its harmful environmental practices by reference to compliance with local and international regulations ("there is no law demanding the restriction" Example 3.10).

By contrast, PUMA, LACOSTE, G-Star RAW responded by aligning themselves with Greenpeace's aims and acquiescing to Greenpeace's demand (Move 3b). This allowed them to sidestep the validity of the charge of misconduct, thus giving them scope to reframe the rhetorical situation. PUMA responded by stating that it "recognises the urgent need for 
reducing and eliminating industrial releases of all hazardous chemicals" (Example 3.14). This statement underlined PUMA's environmental credentials. However, it neither acknowledged the "urgent need" as originating in Greenpeace's 'Dirty Laundry' report nor that PUMA was targeted by Greenpeace in the report. This means that there was no real dialogue between the two parties about the validity of the charge of misconduct. In turn, Greenpeace responded by portraying non-acquiescing firms in a negative light (see Example 3.17 and Example 3.18) (Move 4a) and acquiescing firms in a positive light (see Example 3.19) (Move 4b). This resulted in all six sportswear/fashion firms eventually conceding to Greenpeace's demand. 


\section{Greenpeace accuses sportswear/fashion firms of water pollution:} Move 1 (Accusation) (Press release 1 Greenpeace (1))
Greenpeace demand elimination of hazardous chemicals from the supply chains:

Move 2 (Demand) (Press release 1 Greenpeace (1))

Example 3.3: ...calling on the sportswear giants ${ }^{\text {metaphor }}$ to

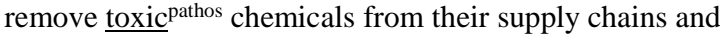
from their products...
- Example 3.1: The Greenpeace International 'Dirty Laundry' ${ }^{\text {pathos }}$ report ... found hazardous chemicals in samples ${ }^{\log o s}$ of wastewater discharges taken at two textile processing facilities..

- Example 3.2: ...snapshot of the kind of toxic ${ }^{\text {pathos }}$ chemicals that are being released by the textile industry into waterways all over the world
Firms' responses to Greenpeace's accusation: Move 3a (Denials, Excuses, Justifications)
Firm responses to Greenpeace's demand: Move 3b (Concessions)

\section{$\underline{\text { adidas }}$}

Excuse - shifts the blame to supplier

(Press release 2 adidas (1))

- Example 3.4: Our business relationship with the Youngor Group is restricted to the cutting and sewing of garments.

- Example 3.5: We have requested Youngor's Management to investigate Greenpeace's claims and, if they are accurate, to take immediate steps for remediation.

- Example 3.6: We have also asked Greenpeace to share with Youngor the specifics of their research, e.g. to disclose all information related to waste water sampling and detection methods to support Youngor's own investigation and remediation process

- Example 3.7: We share Greenpeace concerns about widespread water pollution ${ }^{\text {pathos }}$ in China

- Example 3.8: We do not agree with Greenpeace's conclusion.

\section{$\underline{\mathrm{H} \& \mathrm{M}}$}

Denial of Greenpeace's claim and justification of environmental practices (Press release 11 H\&M (1))

- Example 3.9: The levels of the chemical nonylphenolethoxylate that Greenpeace claim [sic] to have found are below our restricted level of 100 ppm $(=100 \mathrm{mg} / \mathrm{kg})$.

- Example 3.10: There is no law ${ }^{\log o s}$ demanding the restriction

- Example 3.11: The reason for a limit of $100 \mathrm{ppm}$ is that the test methods are uncertain, so a restriction of $0 \mathrm{ppm}$ is not trustworthy.

- Example 3.12: Hence the level of the findings stated are very low, one cannot know that our products contain nonylphenolethoxylate.

- Example 3.13: Our own result and audits done by an independent $\underline{\text { laboratory }}^{\text {ethos }}$ shows [sic] that the chemical has not been used, since the results are below the detection level the independent laboratory ${ }^{\text {ethos }}$ recommends (in this case below $100 \mathrm{ppm}$ ). (see also Example 4.2 where this sentence also illustrates logos)

\section{1 \\ PUMA \\ Concedes to demand}

(Press release 5 PUMA (1))

- Example 3.14: PUMA recognises the urgent need for reducing and eliminating industrial releases of all hazardous chemicals.

- Example 3.15: PUMA is committed to eliminate the discharges of all hazardous chemicals from the whole lifecycle and all production procedures that are associated with the making and using of PUMA products by 2020.

- Example 3.16: An Action Plan will be set up by PUMA within eight weeks from the time this commitment was made.

\section{Greenpeace's response to firms: Move 4a (negative presentation) or Move 4b (positive presentation)}

Punishment-Greenpeace sanctions adidas with activism

(Press release 9 Greenpeace (4))

- Example 3.17: World's largest striptease challenges Adidas and Nike to $\underline{\text { Detox }}^{\text {pathos }}$
Punishment-Greenpeace sanctions $H \& M$ with activism

(Press release 19 Greenpeace (7))

- Example 3.18: ....activists in 12 countries urging the company to come clean ${ }^{\text {metaphor }}$ by attaching "Detox ${ }^{\text {pathos }}$ our future!" stickers to H\&M's shop-windows, and online activists around the world calling on the brand to commit to a toxic$\underline{\text { free }}^{\text {pathos }}$ future
Greenpeace verbally rewards PUMA

(Press release 16 Greenpeace (6))

- Example 3.19: Puma, the world's thirdlargest $^{\text {metaphor }}$ sportswear brand, has responded to a Greenpeace challenge to 'detox' pathos, by publicly committing to the elimination of all releases of hazardous chemicals from its entire product lifecycle, and across its global supply chain by 2020 , putting it firmly ahead $^{\text {metaphor }}$ of its competitors Nike and Adidas in the race ${ }^{\text {metaphor }}$ for a toxicfree $^{\text {pathos }}$ future.

Key: See Table 1 for identification of the specific press releases; underlined words indicate rhetorical strategies (logos, ethos, pathos, metaphor) 


\section{Rhetorical strategies: Logos, ethos, and pathos}

In order to persuade audiences of the validity and legitimacy of their claim, speakers/writers appeal to logic (logos), to authority, (ethos), or to emotion (pathos). Both Greenpeace and the sportswear/fashion firms drew on all three rhetorical strategies when making their claims. Figure 2 conceptualises the interaction between the parties as a series of moves which have specific communicative purposes, i.e., accusing (Move 1), demanding (Move 2), denying (Move 3a) and conceding (Move 3b). Each move manifests itself in the form of a claim with supporting rhetorical strategies (logos, ethos, and pathos) and associated assumptions and beliefs. For example, Greenpeace's statement “The Greenpeace International 'Dirty Laundry' report ... found hazardous chemicals in samples of wastewater discharges taken at two textile processing facilities" (Table 3, Example 3.1) is based on the claim that sportswear/fashion firms were polluting the environment. The underlying assumption is that economic activity systematically produces environmental harm (Everett and Neu, 2000). Consistent with the discourse of ecological modernisation, which underlies this assumption, the evidence is provided in the form of logos (rhetoric of science: 'samples of wastewater discharges' (Table 3, Example 3.1) and reinforced by pathos (metaphor of housekeeping: 'Dirty Laundry report') (Table 3, Example 3.1).

\section{$\underline{\text { Logos (rhetoric of science) and ethos (rhetoric of law and audit) }}$}

The interactions between Greenpeace and the sportswear/fashion firms in the 'Dirty Laundry' case focused on charges of organisational misconduct in the form of harmful environmental practices. Table 4 summarises the use of logos (rhetoric of science) and ethos (rhetoric of law and audit) by Greenpeace and the sportswear/fashion firms, illustrating differences in rhetorical strategies. The rhetoric of science (logos) permeates debates on the environmental impact of business organisations (e.g., pollution, climate change, population growth). Science and scientific rationality, "both in terms of accumulating 'scientific facts' and in posing solutions to environmental problems" (Everett and Neu, 2000, p. 10), play a central role in the discourse of ecological modernisation which has become the dominant discourse of conceptualising the relationships between business organisations and nature. It is widely used by governments, companies, and NGOs (Everett and Neu, 2000; McGregor, 2004). It is therefore not surprising that both sides in the 'Detox' campaign used the rhetoric of science (see examples 4.1, 4.2, 4.3 in Table 4) to convince both the other party and wider audiences of the legitimacy and validity of their arguments, albeit in different ways. Greenpeace used the rhetoric of science as a means of evoking an emotional response ("bioaccumulative hormone disruptors" - Example 4.1), 
whereas the firms tended to use precise chemical formulae and measurements ("Nonylphenolethoxylates", "alkylphenols", “alkylphenolethoxylates" - Example 4.3). The reference in Table 4 to "78 articles tested" (Example 4.7) and "52 were found to contain nonylphenolethoxylates" (Example 4.7) implies objectivity and precision that may not be valid. For example, we do not know the research methods applied that led to this finding. The sample, which is small, may be biased and the amount of chemical found may be very small. As the environmental domain is characterised by stringent regulation, appealing to the authority of the law (ethos) in the form of legal compliance (see examples 4.4, 4.5, 4.6) is also an important means of persuading various audiences of the legitimacy and validity of one's claim. Ethos also entails appealing to independent parties, such as experts or laboratories, to verify environmental performance (see examples 4.7, 4.8, 4.9). 
Table 4: Examples of the rhetoric of science, law, audit/inspection/review

Rhetoric of science (logos) used by Greenpeace to accuse sportswear/fashion firms

- Example 4.1: The chemicals found in the sampling carried out by Greenpeace include persistent and bioaccumulative hormone disruptors (Press release 1 Greenpeace (1))

Rhetoric of science (logos) used by the sportswear/fashion firms contesting Greenpeace's claims

- Example 4.2: Our own result and audits done by an independent laboratory shows [sic] that the chemical has not been used, since the results are below the detection level the independent laboratory recommends (in this case below $100 \mathrm{ppm}$ ). (Press release $11 \mathrm{H} \& \mathrm{M}$ (1)) (see also Example 3.13 where this sentence also illustrates ethos)

Rhetoric of science (logos) used by the sportswear/fashion firms conciliating to Greenpeace's claims

- Example 4.3: Nonylphenolethoxylates (NPEO or NPE) are a class of chemical substances that belong to the general family of chemicals known as alkylphenols (AP) and alkylphenolethoxylates (APEO). (Press release 13 NIKE (3))

Rhetoric of law (ethos) used by Greenpeace to accuse sportswear/fashion firms

- Example 4.4: [Policy makers] can set stringent regulations that systematically reduce and eliminate hazardous chemicals while supporting sustainable innovations (Press release 1 Greenpeace (1))

Rhetoric of law (ethos) used by the sportswear/fashion firms contesting Greenpeace's claims

- Example 4.5: The adidas Group also commissioned a German-based independent testing institute specialised in water analysis to compare testing results as reported in the Greenpeace report with German and European waste and drinking water regulations. (Press release 2 adidas (1))

Rhetoric of law (ethos) used by the sportswear/fashion firms conciliating to Greenpeace's claims

- Example 4.6: EU restriction: $1000 \mathrm{mg} / \mathrm{kg}$ G-Star limit: $100 \mathrm{mg} / \mathrm{kg}$ Greenpeace detection limit: $1 \mathrm{mg} / \mathrm{kg}$ (Press release 12 G-Star RAW (1))

Rhetoric of audit/inspection (ethos) used by Greenpeace to accuse sportswear/fashion firms

- Example 4.7: Of the 78 articles tested, 52 were found to contain nonylphenolethoxylates, chemicals which breaks [sic] down into the hormone-disrupting nonylphenol (Press release 10 Greenpeace (5))

Rhetoric of audit/inspection (ethos) used by the sportswear/fashion firms contesting Greenpeace's claims

- Example 4.8: We conduct about 30000 chemical tests every year to ensure compliance with our chemical restrictions. (Press release $17 \mathrm{H} \& \mathrm{M}(2)$ )

Rhetoric of audit/inspection (ethos) used by the sportswear/fashion firms conciliating to Greenpeace's claims

- Example 4.9: At the moment, G-Star has a compliance system fully focused on hazardous substances, which includes a Restricted Chemicals List, regular checks on the sites, risk assessments, training and support to suppliers, product testing and independent environmental auditing. (Press release 12 G-Star RAW (1))

Key: Key phrases guiding the coding judgement are underlined

In contrast to the firms, Greenpeace hardly used any rhetoric of law or audit (see Table 5 and Table 6). The three firms who denied the charge of wrongdoing defended their environmental practices by reference to local and international laws and regulations. However, organisational legitimacy extends beyond laws and rules and encompasses "a generalized perception or assumption that the actions of an entity are desirable, proper, or appropriate within some 
socially constructed system of norms, values, beliefs, and definitions" (Suchman, 1995, p. 547). This means that a debate on a charge of environmental misconduct is ultimately a debate on the norm-appropriateness of organisational behaviour which cannot be won by reference to rule compliance. By conceding to Greenpeace's demand, the other three firms avoided engaging in a debate on the validity of the charge of wrongdoing, thus protecting their legitimacy and reputation from further damage.

The frequencies of usage of terms associated with the rhetoric of science, law and audit by Greenpeace and the firms is summarised in Table 5. The terms used/basis for the frequency counts in Table 5 are shown in Table 6.

Table 5: Frequency of use of rhetoric of science, law and audit and metaphor

Rhetoric of science, law and audit Greenpeace press releases Sportswear/fashion firms' press releases

Metaphor

Greenpeace press releases

Average per press release

Sportswear/fashion firms' press releases Average per press release

$\begin{array}{rr}\text { Science } & \text { Law } \\ 65 & 1 \\ 94 & 39\end{array}$

Audit
6
49

Total

49

\section{Housekeeping \\ Size \\ Racing Sport Fashion Total}

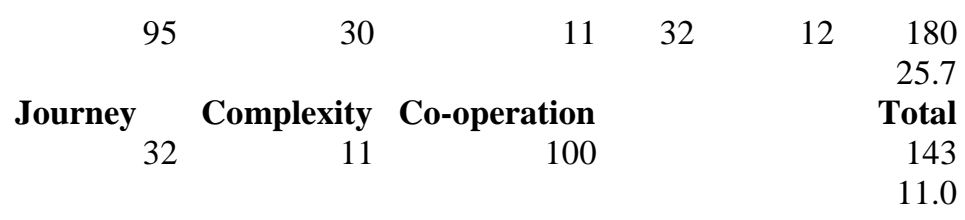


Table 6: Analysis of the frequency of terms used in the rhetoric of science, law and audit

\section{Greenpeace}

(Total length of press releases in words: 5,332 )

\section{Firms}

(Total length of press releases in words: 10,073)

Bioaccumulative

Logos: Rhetoric of science

Hormone disruptors

\begin{tabular}{l|l}
15 & Bioaccumulative
\end{tabular}

Nonylphenolethoxylate, alkylphenols,

Endocrine disruptors

alkylphenolethoxylates,

Nonylphenolethoxylate, alkylphenols, alkylphenolethoxylates,

perflourinatedsulphorates, etc

Other terms referring to science

perflourinatedsulphorates, etc

$\frac{7}{65} \quad$ Other terms referring to science

$\underline{65}$

\begin{tabular}{c|c} 
Ethos: Rhetoric of law \\
0 & European legal regulations
\end{tabular}

European legal regulations

Local regulations

Regulations

$0 \quad$ Local regulations

1 Regulations

Best practice standards

Best practice standards

$\underline{0}$

Ethos: Rhetoric of audit, inspection, review

External audit/Independent review

External audit/Independent review

Internal audit

6

Internal audit

\section{Pathos - Rhetorical use of metaphors}

Both Greenpeace and the sportswear/fashion firms used metaphors rhetorically to persuade the other party and implied audiences (see Figure 2) of the validity of their claims. Table 5 shows the frequency of metaphors used, classified according to the categories summarised in Figure 2 (three of the five categories for Greenpeace, three categories for the firms). Greenpeace used metaphors to a much greater extent than the sportswear/fashion firms. This is in line with the strategy of creative communication outlined in its mission statement. By using metaphors which questioned the sportswear/fashion firms' legitimacy, Greenpeace was able to put pressure on the firms to concede to its demand.

Greenpeace used metaphors (see examples in Table 7a) which draw on collective unconsciously formed sets of beliefs, attitudes, and values (Chateris-Black, 2005, p. 175) underlying Western societies. For example, the title of its first report, 'Dirty Laundry' report, uses the metaphor of housekeeping ('dirty laundry' - Example 7.2 in Table 7a, 'clean up their acts' - Example 7.1) embedded in the popular saying 'washing your dirty laundry/linen in public' to refer to the pollution by the sportswear/fashion industry. The power of this metaphor derives from its inherent dualism, i.e., clean versus dirty. Whereas cleanliness is associated 
with morality (i.e., godliness), dirt is associated with amorality (i.e., vice). This allowed Greenpeace to construct the practices of sportswear/fashion firms as both physically and morally 'dirty'. As this metaphor resonates with the belief system of Western societies, Greenpeace was able to psychologically connect with its various audiences, including consumers, environmentalists, and the media. They, in turn, have the ability to put pressure on the sportswear/fashion firms to abolish their harmful environmental practices by product boycotts, protests, and negative publicity. The metaphor of size ('giants' - Example 7.6 in Table 7a) constructed the sportswear/fashion firms as important powerful organisational actors. This rendered Greenpeace's plea for action both compelling and viable. What is more, in the dominant capitalist ideology, size is associated with importance, growth, and power. Both metaphors resonate strongly with the beliefs system of Western capitalist societies. This made it difficult for sportswear/fashion firms to counter Greenpeace's charge of misconduct with pathos. Thus, sportswear/fashion firms contesting Greenpeace's accusation of environmental misconduct resorted to logos (rhetoric of science) and ethos (reference to the authority of the law and to the authority of independent testing) to defend their environmental practices.

Greenpeace framed its demand to eliminate all hazardous chemicals both as a race and as a fashion contest, thus pitting the firms against each other in a competition to reach this target. Greenpeace used the metaphors of sport and fashion to construct the firms conciliating to its demand as winners, champions (examples 7.9, 7.10, 7.11, 7.12) and trendsetters (examples 7.18, 7.19, 7.20) in Table 7a and the firms resisting its demand as 'losers' (examples 7.13, 7.14, 7.15. 7.16, 7.17) and unfashionable (Example 7.21). As consumer goods firms are highly dependent on public opinion, this positive/negative labelling by Greenpeace (Move $4 \mathrm{~b}$ positive presentation and Move 4a negative presentation) was aimed at influencing public perception and thus risked impacting on organisational reputation and legitimacy. As a result, all six sportswear/fashion firms which engaged in verbal interaction with Greenpeace eventually agreed to Greenpeace's demand. The metaphors of racing, sport and fashion are powerful, as they tap into the dominant capitalist ideology which emphasises competition and success. Goatly (2007) argues that metaphors of speed involve the conceptualisation of a process or an activity as motion, regardless of whether it involves movement or not. The intensity at which an activity takes place, is then associated with speed. Thus, speed metaphors tend to double up as metaphors for success. Greenpeace cleverly linked the association between speed and success with the firms' products (sportswear and fashion) to construct the elimination of hazardous chemicals from their supply chains as a competition between firms. What is more, 
Western fashion functions as an aesthetic medium for the expression of ideas, desires, and beliefs circulating in society (Counsell and Wolf, 2001, p. 150). Environmental concerns have gained prominence in Western societies (McGregor, 2004). Using the metaphor of fashion, Greenpeace exploited the fashion firms' dependency on being perceived at the forefront of ideas, desires, and beliefs. Thus, firms conceding to Greenpeace's demand are constructed as 'trendsetters' and firms refusing to do so as old-fashioned.

The sportswear/fashion firms countered Greenpeace's demand for the elimination of hazardous chemicals from their supply chains by using the metaphors of journey, complexity and cooperation (pathos) (see Table 7b) which redefined Greenpeace's target as a complex process involving a collaborative effort by the sportswear/fashion industry. They strategically used the concepts of slowness and co-operation to gain time. Slowness and co-operation, the nondominant aspect of the metaphors of speed and competition, are particularly valued by environmentalists and other counter-culture groups in society (e.g., the slow food movement, the rat race). The journey metaphor constitutes a predominant metaphor in business discourse on sustainability used in annual reports, press releases, and CEO speeches (Milne et al., 2006). However, it also functions as a means of obfuscation, as it simultaneously evokes the impression of engaging with and progressing towards sustainability, yet masks the actual destination of the journey by describing it as a "long, difficult, on-going, perhaps never ending, and ill-defined" process (Milne et al., 2006, p. 820). However, in its 'Detox' campaign Greenpeace defined the end point of 'the journey' both in terms of outcome and time-frame as the elimination of hazardous chemicals from the firms' supply chains by 2020 . This suggests that Greenpeace was not only aware of the risk of corporate greenwash (i.e., merely influencing audiences' perceptions of environmental performance, rather than improving environmental performance), but also aimed to prevent targeted companies from engaging in it.

In conclusion, both Greenpeace and the sportswear/fashion firms used the rhetorical strategy of pathos in the form of metaphors embodying the values of the other party to persuade them of the validity of their argument. What is more, both sides involved in the conflict used the rhetorical strategy of logos (rhetoric of science) in line with the dominant discourse of ecological modernisation which advocates sustainable economic development based on the principles of scientific environmental management. The rhetorical strategy of ethos (rhetoric of law, audit, and inspection) aimed at persuading audiences of the need for stringent environmental regulation (Greenpeace) or of the compliance with environmental standards and 
regulations (firms) is in line with the assumption that economic activity systematically produces environmental harm (Everett and Neu, 2000). Constructing an issue, such as pollution, in the language of the dominant discourse is a powerful way of presenting an argument and influencing opinion, as dominant discourses do not require lengthy explanation or legitimisation because they are familiar, recognisable, and accepted by a variety of audiences (McGregor, 2004, p. 598). 
Table 7a: Use of metaphors by Greenpeace

Housekeeping (Laundry) metaphors: Used by Greenpeace to accuse sportswear/fashion firms (Move 1)

- Example 7.1: As industry frontrunners, major sportswear brands have a responsibility to show leadership and clean up their acts (Press release 4 Greenpeace (2))

- Example 7.2: ...global brands like Adidas are expecting customers to do their dirty laundry for them (Press release 10 Greenpeace (5))

- Example 7.3: Brands must ... come clean about what chemicals their factories are using and discharging (Press release 10 Greenpeace (5))

Housekeeping (Laundry) metaphors: Used to reward sportswear/fashion firms conceding to Greenpeace's claims (Move 4b)

- Example 7.4: By committing to clean up its dirty laundry, Nike is showing real winning form (Press release 9 Greenpeace (4))

Housekeeping (Laundry) metaphors: Used to punish sportswear/fashion firms contesting Greenpeace's claims (Move 4a)

- Example 7.5: To highlight this problem and the need for urgent solutions, activists in the Philippines today hung out tshirt shaped banners exposing the 14 brands 'Dirty Laundry' over the Marikina River, challenging them to "Cut the chemicals and Detox our water". (Press release 10 Greenpeace (5))

Size metaphors: Used to apply pressure on sportswear/fashion firms to concede to Greenpeace's demand

- Example 7.6: ...calling on the sportswear giants to remove toxic chemicals from their supply chain (Press release 1 Greenpeace (1))

- Example 7.7: Puma, the world's third-largest sportswear brand (Press release 16 Greenpeace (6))

- Example 7.8: ... major fashion brands (Press release 19 Greenpeace (7))

Racing metaphors: Used to reward sportswear/fashion firms conceding to Greenpeace's claims (Move 4b)

- Example 7.9: Nike Scores 1-0 Over Adidas with toxic pollution clean-up commitment (Press release 9 Greenpeace (4))

- Example 7.10: Round one of the Detox challenge goes to Puma (Press release 6 Greenpeace (3))

- Example 7.11: ...putting it [Puma] firmly ahead of its competitors Nike and Adidas in the race for a toxic-free future (Press release 6 Greenpeace (3))

- Example 7.12: Nike is showing real winning form (Press release 9 Greenpeace (4))

Racing metaphors: Used to punish sportswear/fashion firms contesting Greenpeace's claims (Move 4a)

- Example 7.13: ...now Nike and Adidas better get in gear, or else risk falling behind in the race towards a toxic-free future (Press release 6 Greenpeace (3))

Sporting metaphors: Used to punish sportswear/fashion firms contesting Greenpeace's claims (Move 4a)

- Example 7.14: ... losers shouldn't throw in the towel (Press release 9 Greenpeace (4))

- Example 7.15: ... water pollution is not fair play (Press release 9 Greenpeace (4))

- Example 7.16: Adidas and Nike are playing on the same team as toxic polluters (Press release 4 Greenpeace (2))

- Example 7.17: Adidas and Nike talk a good game (Press release 4 Greenpeace (2))

Fashion metaphors: Used to reward sportswear/fashion firms conciliating to Greenpeace's claims (Move 4b)

- Example 7.18: ...this season's hottest fashion trend (Press release 19 Greenpeace (7))

- Example 7.19: ... setting the trend for this season and the future (Press release 19 Greenpeace (7))

- Example 7.20: ... "detoxing" is back in fashion, with a number of clothing brands publicly engaging in the "Detox" challenge (Press release 16 Greenpeace (6))

Fashion metaphors: Used to punish sportswear/fashion firms contesting Greenpeace's claims (Move 4a)

- Example 7.21: ... it also sends a clear message to other brands that using toxic chemicals to make our clothing is no longer in vogue (Press release 19 Greenpeace (7))

Key: Key phrases guiding the coding judgement are underlined 
Table 7b: Use of metaphors by the sportswear/fashion firms

Journey metaphors

- $\quad$ Example 7.22: Driving industry collaboration for the development of a dye-house audit protocol (phrase repeated Press releases $2 \& 3$ adidas (1) \& (2))

- Example 7.23: To make this a reality, NIKE, Inc. will continue phasing out hazardous chemicals in our supply chain and we will accelerate the phase out of the highest priority hazardous chemicals (Press release 7 NIKE (1))

Metaphors of complexity

- Example 7.24: This work is done within a complex and tiered network of buyers, agents, distributors and material suppliers (Press release 8 NIKE (2))

- Example 7.25: The supply chain of a garment is a very complex system with as many steps and suppliers in the chain as parts and raw materials used (Press release 12 G-Star RAW (1))

Metaphors of co-operation

- Example 7.26: We always strive to strengthen our methods and routines, and as part of our work we wellcome [sic] the dialogue with all our stakeholders - of course including Greenpeace (Press release 11H\&M (1))

Key: See Table 1 for identification of the specific press releases; Key phrases guiding the coding judgement are underlined

\subsection{The rhetorical situation in the 'Dirty Laundry' case}

As shown in Figure 3, Greenpeace's press releases simultaneously served three purposes: (1) to persuade firms to eliminate hazardous chemicals from their supply chains, (2) to persuade consumers and environmentalists to put pressure on firms by product boycotts and participating in protest activities, and (3) to persuade governments and policy makers to introduce tighter environmental regulations. Conversely, the press releases of the sportswear/fashion firms also served three purposes: (1) to deny Greenpeace's charge of wrongdoing or to concede to Greenpeace's demand, (2) to prevent product boycotts and (3) to prevent increased regulation by highlighting good environmental practices and aligning themselves with Greenpeace's cause.

Greenpeace is a stakeseeker, as it aimed to exert influence over the firms' environmental practices, policies, and performance without having any organisationally defined links to them. Prior to the first 'Dirty Laundry' report, Greenpeace is a dominant stakeholder for firms with a high-street or strong brand presence (i.e., operating predominantly in the retail and food sector) in that it combines power and legitimacy gained through a variety of successful campaigns targeting these industries (Cooper, 2009). Figure 4 indicates that the presence of pollution in the supply chains of the sportswear/fashion industry provided Greenpeace with an urgent claim, thus transforming it from a dominant to a definitive stakeholder. The urgency of the claim (see discussion in the next section) manifested itself rhetorically by means of the 
metaphor of racing in Greenpeace's press releases. During the 'Detox' campaign, Greenpeace skilfully used its power and legitimacy to access symbolic resources in the form of support by activists, consumers, the government/policy makers, the general public and the media (see dotted arrows indicating influence in Figure 4). This support results from Greenpeace successfully persuading audiences that the firms' environmental practices and policies violated social norms and rules relating to pollution, thus creating a legitimacy threat. Consumers, government/policy makers and the media are dominant stakeholders in the sense that they have both power (i.e., access to financial and symbolic resources) and legitimacy. By persuading them of the urgency of the claim, they have the potential to become definitive stakeholders who can exercise their power in the form of product boycotts, more stringent environmental regulations and negative portrayal in the media (see broken arrow indicting potential action in Figure 4). By contrast, activists are dormant stakeholders in the sense that they have power to impose their will on organisations by means of campaigns which attract the attention of the media. By persuading them of the urgency of the issue, Greenpeace mobilised activists to participate in high-profile events, such as a mass-striptease, activism during a football match, and a sticker campaign (see arrows indicating action in Figure 4). This transformed them into dangerous stakeholders who used their power to coerce the firms to commit to Greenpeace's demand. These events were reported in the media, thereby not only creating negative publicity and threatening the firms' reputation and legitimacy, but also influencing the perceptions of the consumers of sportswear/fashion goods. Greenpeace subsequently rendered the support by activists explicit in its press releases (see Example 3.17 and Example 3.18 in Table 3).

\section{Summary and implications}

We examined the use of rhetoric and argument in social and environmental reporting in the 'Dirty Laundry' case which involved a conflict between Greenpeace and firms in the sportswear/fashion industry over the use of hazardous chemicals in their supply chains. Both sides used the rhetorical strategies of logos, ethos, and pathos to convince audiences of the validity and legitimacy of their claims. Greenpeace skilfully used pathos (i.e., appealing to audiences' emotions) in the form of metaphors associated with the dominant capitalist ideology underpinning Western societies (metaphors of housekeeping, size, racing, sport and fashion) to expose the harmful environmental practices of fashion/sportswear firms and to demand their improvement. This is in line with Greenpeace's strategy to use creative communication to achieve its aims, as outlined in its mission statement. Greenpeace also used the rhetoric of science, law, audit, and inspection which underpin the dominant discourse of ecological 
modernisation. Based on "the accumulation of scientific evidence of environmental impacts" (Harvey, 1998, p. 343; quoted in Everett and Neu, 2000, p. 11), the rhetoric of science provides a familiar and thus accepted way of conceptualising pollution. What is more, the assumption that economic activity systematically produces environmental harm which underlies the discourse of ecological modernisation necessitates "proactive strategies, preventative practices, and rigid and systematic politics, institutional arrangements and regulatory practices" (Everett and Neu, 2000, p. 9). These are evident in the rhetoric of law, audit, and inspection used by Greenpeace.

The sportswear/fashion firms eventually conceded to Greenpeace's demand by using metaphors based on values and beliefs of the environmental movement (journey, complexity, and co-operation). This enabled them to reframe the elimination of hazardous chemicals from their supply chain as a complex process, thus allowing them to buy some time. Both Greenpeace and the firms used metaphors associated with the other party's belief system to persuade them of the validity and legitimacy of their claims. This indicates that the use of pathos, particularly in the form of metaphors which are associated with the value system of the respective audience, constitutes a powerful method of persuasion.

Our findings suggest that the outcome of conflicts on social and environmental issues is dependent on the particular attributes of the stakeholder involved and the stakeholder's ability to harness the power and legitimacy of other key stakeholders. Firms find it difficult to ignore the demand of powerful and legitimate stakeholders who have urgent claims. Power derives from the ability to access material and symbolic resources. Our findings suggest that, in social and environmental conflicts, access to financial resources is less crucial than the ability to gain support from key stakeholders, such as environmental activists, consumers, the general public and the media. This support depends on the stakeholder's rhetorical skill in persuading audiences that the firms' environmental practices and policies violate social norms and rules. The use of metaphors allows parties involved in a conflict to frame and reframe the contested issue in particular ways. Thus, rhetoric plays a key role in the way the conflict is resolved. Our findings suggest that Greenpeace combines all three attributes of a 'clever' stakeholder, namely skills in coalition-building, political action, and social reality construction (Mitchell et al., 1997, p. 879). For this reason, the sportswear/fashion firms found it impossible to ignore Greenpeace's demand and eventually all committed to the elimination of hazardous chemicals from their supply chains. This is in line with the view that language is a mechanism of power through which constituents pursue their interests (Bourdieu, 1991). 
It is too early to say whether Greenpeace's 'Detox' campaign will lead to substantive changes in manufacturing processes, rather than just greenwash. If the firms do not follow through with their commitments, this puts Greenpeace's reputation as a change agent at risk. Greenpeace took advantage of the intense competition between the sportswear/fashion firms in order to ensure their compliance. If the firms do not deliver on their promises, they face the risk of further Greenpeace activism resulting in negative publicity. The fourth Greenpeace report on the use of hazardous chemicals by the sportswear/fashion industry, 'Toxic Threads - The Big Fashion Stitch-Up', published in November 2012, shows that Greenpeace kept up the pressure on the firms by playing on the competition in the fashion industry. Greenpeace classified the firms into four categories, depending on the strength of their commitment to Greenpeace's 'Detox' challenge and their individual strategies to eliminate hazardous chemicals from the supply chains. 'Engaged detox brands' are firms that have made the zero discharge commitment and have implemented individual action plans (including five of the six firms discussed in this paper). 'Detox greenwashers' are firms that have made the zero discharge commitment, but have not implemented individual action plans (including G-Star RAW). 'Detox laggards' are firms that have not made the zero discharge commitment, but that have individual chemical management policies. 'Detox villains' are firms that have neither made the zero discharge commitment, nor implemented individual chemical management policies.

In this paper we only focus on one aspect of communication (written communication in the form of press releases) between the parties involved in the 'Dirty Laundry' case. However, Greenpeace also used visual rhetoric (a video, posters and placards) and the rhetoric of performance (social activism in the form of a strip-tease, a sticker campaign, etc.) to put pressure on the firms to concede to its demand. These non-verbal forms of communication constitute a powerful means of persuasion and undoubtedly contributed to the outcome of the conflict. Prior research has focused on the use of visuals in corporate annual reports to convey a particular message. However, we know little about the use of non-verbal means of communication by stakeholders, and even less about the use of non-verbal means of communication during interactions between business organisations and stakeholders. Images have a strong psychological impact and therefore constitute an even more powerful way of persuasion than words. In order to understand the dynamics of communication between business organisations and their various audiences, future research needs to explore non-verbal 
as well as verbal communication. This necessitates interdisciplinary research drawing on insights from visual arts and drama. 


\section{REFERENCES}

Alpaslan, C.M., Green, S.E. and Mitroff, I.I. (2009), "Corporate governance in the context of crises: towards a stakeholder theory of crisis management", Journal of Contingencies and Crisis Management, Vol. 17 No. 1, pp. 39-49.

Amernic, J.H. and Craig, R.J. (2009), "Understanding accounting through conceptual metaphor: accounting as an instrument", Critical Perspectives on Accounting, Vol. 20 No. 8, pp. $875-883$.

Amernic, J., Craig, R. and Tourish, D. (2007), “The charismatic leader as pedagogue, physician, architect, commander, and saint: Five root metaphors in Jack Welch's letters to stockholders of General Electric", Human Relations, Vol. 60 No. 12, pp. 1839-1872.

Amossy, R. (2001), "Ethos at the crossroads of disciplines: rhetoric, pragmatics, sociology", Poetics Today, Vol. 22 No. 1, pp.1-23.

Aristotle (2010), Rhetoric, translated by W. Rhys Roberts, The Pennsylvania State University, PA.

Ashforth, B. and Gibbs, B. (1990), "The double-edged sword of organizational legitimation", Organization Science, Vol. 1 No. 2, pp. 177-194.

Austin, J.L. (1962), How to Do Things with Words, Oxford University Press, London.

Bebbington, J., Brown, J. Frame, B. and Thomson, I. (2007), "Theorizing engagement: the potential of a critical dialogic approach", Accounting, Auditing \& Accountability Journal, Vol. 20 No. 3, pp. 356-381.

Beelitz, A. and Merkl-Davies, D.M. (2012), "Using discourse to restore organizational legitimacy: 'CEO-speak' after an incident in a German nuclear power plant', Journal of Business Ethics, Vol. 108 No. 1, pp. 101-120. 
Benoit, W.L. (1997), "Image repair discourse and crisis communications", Public Relations Review, Vol. 23 No. 2, pp. 177-186.

Benoit, W.L. and Czerwinski, A. (1997), "A critical analysis of USAir's image repair discourse", Business Communication Quarterly, Vol. 60 No. 3, pp. 38-57.

Bernays, E.L. (1947), "The engineering of consent", The Annals of the American Academy of Political and Social Science, Vol. 250 No. 1, pp. 113-120.

Billig, M., Condor, S., Edwards, D., Gane, M., Middleton, D. and Radley, A.R. (1988), Ideological Dilemmas: A Social Psychology of Everyday Thinking, Sage, London.

Bourdieu, P. (1991), Language and Symbolic Power, Polity Press, Cambridge and Malden.

Brennan, N.M., Daly, C.A. and Harrington, C.S. (2010), "Rhetoric, argument and impression management in hostile takeover defence documents", British Accounting Review, Vol. 42 No. 4, pp. 253-268.

Brennan, N. and Gray, S.J. (2000), Rhetoric and Argument in Financial Reporting: Disclosures in Profit Forecasts and Takeover Documents. Association of Chartered Certified Accountants Occasional Research Paper No. 31, Certified Accountants Educational Trust, London.

Brennan, N.M., Merkl-Davies, D.M. and Beelitz, A. (2013), "Dialogism in corporate social responsibility communications: conceptualising verbal interactions between organisations and their audiences", Journal of Business Ethics, Vol. 115 No. 4, pp. 665-679.

Carter, S.M. (2006), “The interaction of top management group, stakeholder, and situational factors on certain corporate reputation management activities", Journal of Management Studies, Vol. 43 No. 5, pp. 1145-1176.

Castelló, I. and Lozano, J.M. (2011), "Searching for new forms of legitimacy through corporate responsibility rhetoric”, Journal of Business Ethics, Vol. 100 No. 1, pp. 11-29. 
Charteris-Black, J. (2004), Corpus Approach to Critical Metaphor Analysis, PalgraveMacmillan, Basingstoke.

Charteris-Black, J. (2005), Politicians and Rhetoric: The Persuasive Power of Metaphor, Palgrave-Macmillan, Basingstoke.

Cheney, G., Christensen, L.T., Conrad, C. and Lair, D.J. (2004), "Corporate rhetoric as organisational discourse", in Grant, D., Hardy, C., Oswick, C. and Putnam, L. (eds) The SAGE Handbook of Organizational Discourse, Sage Publications, London, pp. 79-104.

Cooper, A.D. (2009), “Two-way communication: a win-win model for facing activist pressure: a case study on McDonalds and Unilever's responses to Greenpeace", Master of Arts in Public Relations dissertation, Ball State University, Indiana.

Counsell, C. and Wolf, L. (2001), Performance Analysis: An Introductory Coursebook, Routledge, Milton Park.

Coupland, C. (2005), "Corporate social responsibility as argument on the web", Journal of Business Ethics, Vol. 62 No. 4, pp. 355-366.

Cox, J.W. (2012), “Action research”, in Symon, G. and Cassell, C. (eds.), Qualitative Organizational Research: Core Methods and Current Challenges, Sage Publications, Thousand Oaks, CA, pp. 371-388.

Craig, R.J. and Amernic, J.H. (2004a), “The deployment of accounting-related rhetoric in the prelude to privatization", Accounting, Auditing and Accountability Journal, Vol.17 No. 1, pp. 41-58.

Craig, R.J. and Amernic, J.H. (2004b), "Enron discourse: the rhetoric of a resilient capitalism”, Critical Perspectives on Accounting, Vol. 15 No. 6/7, pp. 813-851.

Craig, R.J. and Amernic, J.H. (2008), “A privatization success story: accounting and narrative expression over time”, Accounting, Auditing \& Accountability Journal, Vol. 21 No. 8, pp. 1085-1115. 
Crown, S. (2009), “Anne Michaels, fugitive author”, The Guardian, Sat. $2^{\text {nd }}$ May 2009. http://www.guardian.co.uk/books/2009/may/02/interview-anne-michaels.

Crowther, D., Carter, C. and Cooper, S. (2006), "The poetics of corporate reporting: evidence from the UK water industry", Critical Perspectives on Accounting, Vol. 17 No. 1-2, pp. 175201.

DeRosa, S.L. and Ferruci, S.A. (2011), Choices Writers Make: A Guide, Longman, London.

De Tienne, K.B. and Lewis, L.W. (2005), “The pragmatic and ethical barriers to corporate social responsibility disclosure: the Nike case", Journal of Business Ethics, Vol. 60 No. 4, pp. 359-376.

Elsbach, K.D. (1994), "Managing organizational legitimacy in the California cattle industry: the construction and effectiveness of verbal accounts", Administrative Science Quarterly, Vol. 39 No. 1, pp. 67-88.

Elsbach, K.D (2001), “The architecture of legitimacy: constructing accounts of organisational controversies", In Jost, J.T. and Major, B. (Eds.), The Psychology of Legitimacy, Cambridge University Press, Cambridge, pp. 391-415.

Everett, J. and Neu, D. (2000), "Ecological modernization and the limits of environmental accounting?", Accounting Forum, Vol. 24 No. 1, pp. 5-29.

Fassin, Y. (2009), "Inconsistencies in activists' behaviours and the ethics of NGOs", Journal of Business Ethics, Vol. 90 No. 4, pp. 503-521.

Freeman, R.E. (1984), Strategic Management: A Stakeholder Approach, Pitman, Boston, MA. 
Gabriel, Y. (2004), "Narratives, stories, and texts", in Grant, D., Hardy, C., Oswick, C. and Putnam, L. (eds.), The SAGE Handbook of Organizational Discourse, Sage Publications, London, pp. 61-77.

Ginzel, L.E., Kramer, R.M. and Sutton, R.I. (2004) "Organisational impression management as a reciprocal influence process: the neglected role of the organisational audience", In Hatch, M.J. and Schultz, M. (eds.), Organisational Identity, Oxford University Press, Oxford, pp. 223261.

Goatly, A. (2007), Washing the Brain: Metaphor and Hidden Ideology, John Benjamins. Amsterdam.

Gray, R., Owen, D. and Maunders, K. (1987), Corporate Social Reporting, Prentice-Hall, Englewood Cliffs, NJ.

Greenpeace USA (2013), “Greenpeace Annual Report 2012”, Greenpeace, San Francisco, CA.

Harvey, D. (1998), “What's green and makes the environment go round?”, In Jameson, F. and Miyoshi, M. (eds.), The Cultures of Globalization, Duke University Press, Durham, NC, pp. 327-355.

Heath, R.L. (1997), Strategic Issues Management: Organisations and Public Policy Challenges. Sage, Thousand Oaks, CA.

Higgins, C. and Walker, R. (2012), "Ethos, logos, pathos: strategies of persuason in social/environmental reports", Accounting Forum, Vol. 36 No. 3, pp. 194-208.

Holzer, B. (2008), "Turning stateseekers into stakeholders: a political coalition perspective on the politics of stakeholder interests", Business \& Society, Vol. 47 No. 1, pp. 50-67.

Hooghiemstra, R. (2000), "Corporate communication and impression management - new perspectives why companies engage in corporate social reporting", Journal of Business Ethics, Vol. 27 No. 1, pp. 55-68. 
Jawahar, I. M. and McLaughlin, G.L. (2001), "Toward a descriptive stakeholder theory: an organizational life cycle approach", Academy of Management Review, Vol. 26 No. 3, pp. 397414.

Joutsenvirta, M. (2011), "Setting boundaries for corporate social responsibility: firm-NGO relationship as a discursive legitimation struggle", Journal of Business Ethics, Vol. 102 No. 1, pp. 57-75.

Ketola, T. (2006), "Corporate psychological defences: an oil spill case”, Journal of Business Ethics, Vol. 65 No. 2, pp. 149-161.

Ketola, T. (2008), "A holistic corporate responsibility model: integrating values, discourses and actions", Journal of Business Ethics, Vol. 80 No. 3, pp. 419-435.

Lakoff, G. and Johnson, M. (1980), Metaphors We Live By, University of Chicago Press, Chicago, IL.

Linsley, P. and Kajüter, P.M. (2008), "Restoring reputation and repairing legitimacy.A case study of impression management in response to a major risk event at Allied Irish Banks plc", International Journal of Financial Services Management, Vol. 3 No. 1, pp. 65-82.

Llewellyn, S. (2003), "What counts as 'theory' in qualitative management and accounting research? Introducing five levels of theorizing", Accounting, Auditing and Accountability Journal, Vol. 16 No. 4, pp. 662-705.

Massey, J.E. (2001), “Managing organizational legitimacy: communication strategies for organizations in crisis", Journal of Business Communication, Vol. 38 No. 2, pp. 153-183.

Mathews, M.R. and Perera, M.H.B. (1985), Accounting Theory and Development, third edition, Thomas Nelson Australia, Melbourne.

McGregor, A. (2004), "Sustainable development and 'warm fuzzy feelings': discourse and nature within Australian environmental imaginaries", Geoforum, Vol. 35 No. 5, pp. 593-606. 
Milne, M.J., Kearins, K. and Walton, S. (2006), "Creating adventures in wonderland: the journey metaphor and environmental sustainability", Organization, Vol. 13 No. 6, pp. 801834.

Mitchell, R.M., Agle, B.R. and Wood, D.J. (1997), "Toward a theory of stakeholder identification and salience: Defining the principle of who and what really counts", Academy of Management Review, Vol. 22 No 4, pp. 853-886.

Morgan, G. (1980), "Paradigms, metaphors and puzzle solving in organization theory", Administrative Science Quarterly, Vol. 25 No. 4, pp. 605-622.

Morgan, G. (1983), "More on metaphor: why we cannot control tropes in administrative science", Administrative Science Quarterly, Vol. 28No. 4, pp. 601-607.

Morgan, G. (1993), Imagination. The Art of Creative Management. Sage, Beverly Hills, CA.

Ogden, S. and Clarke, J. (2005), "Customer disclosures, impression management and the construction of legitimacy: corporate reports in the UK privatised water industry", Accounting, Auditing and Accountability Journal, Vol. 18 No. 3, pp. 313-345.

Reisigl, M. (2008), "Analysing political rhetoric”, In Wodak, R. and Krzyzanowski, M. Qualitative Discourse Analysis in the Social Sciences, Palgrave Macmillan, Houndsmills.

Ross, A. (ed.) (1997), No Sweat. Fashion, Free Trade and the Rights of Garment Workers, Verso, London.

Searle, J.R. (1969), Speech Acts. Cambridge University Press, Cambridge.

Suchman, M.C. (1995), "Managing legitimacy: strategic and institutional approaches", Academy of Management Review, Vol. 20 No. 3, pp. 571-610.

Suddaby, R. and Greenwood, R. (2005), "Rhetorical strategies of legitimacy", Administrative Science Quarterly, Vol. 50 No. 1, pp. 35-67. 
Thibodeau, P.H. and Boroditsky, L. (2011), "Metaphors we think with: the role of metaphor in reasoning”, PLoS ONE, Vol. 6 No. 2, pp. 1-11.

Tregidga, H., Milne, M. and Kearins, K. (2007), “The role of discourse in bridging the text and context of corporate social and environmental reporting", Paper presented at the Asia Pacific Interdisciplinary Research in Accounting (APIRA) Conference, Auckland, New Zealand. Available at http://195.130.87.21:8080/dspace/handle/123456789/293 (retrieved 18 April 2013).

Tsoukas, H. (1999), "David and Goliath in the risk society”, Organization, Vol. 6 No. 3, pp. 499-526.

Vidal, J. (1997), McLibel: Burger Culture on Trial, New Press, New York.

Walters, M. (2004), “Alternative accounting thought and the prison-house of metaphor", Accounting, Organizations and Society, Vol. 29 No. 2, pp. 157-187.

Weber, M. (1958), The Protestant Ethic and the Spirit of Capitalism, Scribners, New York.

Wetherell, M. and Potter, J. (1988), "Discourse analysis and the identification of interpretative repertoires", in Antaki, C. (ed.) Analysing Everyday Explanation: A Casebook of Methods, Sage Publications, London, pp. 168-183.

Wood, D.J. (1991), "Corporate social performance revisited", Academy of Management Review, Vol. 16 No. 4, pp. 691-718. 